\title{
5. SEDIMENTOLOGY AND ISOTOPIC CHEMISTRY OF THE BENGAL FAN SEDIMENTS: THE DENUDATION OF THE HIMALAYA ${ }^{1,5}$
}

\author{
Anne Bouquillon, ${ }^{2}$ Christian France-Lanord, ${ }^{3}$ Annie Michard, ${ }^{3}$ and Jean-Jacques Tiercelin ${ }^{4}$
}

\begin{abstract}
Mineralogical and $\mathrm{H}, \mathrm{O}, \mathrm{Sr}$, and $\mathrm{Nd}$ isotope compositions have been analyzed on a set representative samples from the $17-\mathrm{m} . \mathrm{y}$. section in ODP Leg 116 Holes $717 \mathrm{C}$ and $718 \mathrm{C}$. Based on the mineralogical composition of the fraction $<2 \mu \mathrm{m}$ together with the lithogenic-biogenic composition of the fraction $>63 \mu \mathrm{m}$, the whole section can be subdivided into three major periods of sedimentation. Between 17.1 and $\approx 6 \mathrm{~m}$.y., and between $\approx 0.8 \mathrm{~m}$.y. to present, the sediments are characterized by sandy and silty turbiditic inputs with a high proportion of minerals derived from a gneissic source without alteration. In the fraction $<2 \mu \mathrm{m}$, illite and chlorite are dominant over srnectite and kaolinite. The granulometric fraction $>63 \mu \mathrm{m}$ contains quartz, muscovite, biotite, chlorite, and feldspars. The 6-to 0.8-m.y. period is represented by an alternation of sandy/silty horizons, muds, and calcareous muds rich in smectite, and kaolinite ( $50 \%$ to $85 \%$ of the fraction $<2 \mu \mathrm{m}$ ) and bioclastic material. The presence of smectite and kaolinite, as well as the ${ }^{18} \mathrm{O} /{ }^{16} \mathrm{O}$ and the ${ }^{87} \mathrm{Sr} /{ }^{86} \mathrm{Sr}$ ratios of the fraction $<2 \mu \mathrm{m}$, imply an evolution in a soil environment and exchanges with meteoric ground water.

The ranges of isotopic compositions are limited throughout the section: $\delta^{18} \mathrm{O}$ quartz $=11.7$ to $13.3 \%,{ }^{87} \mathrm{Sr} /{ }^{86} \mathrm{Sr}$ $=0.733$ to 0.760 and $\epsilon \mathrm{Nd}_{\mathrm{o}}=-17.4$ to -13.8 . These values are within those of the High Himalaya Crystalline series, and they are considered to reflect this source region. The data imply that, since $17 \mathrm{Ma}$, this formation has supplied the major part of the eroded material.
\end{abstract}

\section{INTRODUCTION}

The Bengal Fan deposits stretch more than $2,500 \mathrm{~km}$ south of the Ganges-Brahmaputra Delta. They form the greatest sedimentary accumulation in the world, being more than 12 $\mathrm{km}$ thick under the upper fan, and result from the greatest influx of particulate matter to the oceans ( $24 \%$ of the total flow of particles to the oceans) (Milliman and Meade, 1983). Beside their immediate interest for sediment transportation and deposition mechanism studies, these deposits record the history of uplift and erosion processes in the Himalayas (Gansser, 1966; Curray and Moore, 1971; Leg 116 Shipboard Scientific Party, 1987). Using combined sedimentological, mineralogical, and isotopic approaches, our purposes are:

1. To determine the sources of the detrital sediments from the Miocene to the Present. The principal sources must be in the Himalayas as indicated by the great thickness of eroded crust (more than $10 \mathrm{~km}$ ). However, considering the extreme distal fan position of Leg 116 sites (Fig. 1), it is possible that the adjacent seamounts (Afanaziy Nikitin) or the old continental crusts of Sri Lanka and eastern India have also contributed some material.

2. To assess the evolution of the detrital minerals from their source to their depositional area, under the cumulative effects of weathering, transportation and successive phases of sedimentation and reworking.

\footnotetext{
${ }^{1}$ Cochran, J. R., Stow, D.A.V., et al., 1990. Proc. ODP, Sci. Results, 116: College Station, TX (Ocean Drilling Program).

${ }^{2}$ Laboratoire de Dynamique sédimentaire et structurale, Université des Sciences et Techniques de Lille-Flandre-Artois, 59655-Villeneuve d'Ascq Cedex, France.

${ }^{3}$ Centre de Recherches Pétrographiques et Géochimiques, C.N.R.S., 54501-Vandoeuvre Cedex, France.

${ }^{4}$ GDR "Genèse et Evolution des Domaines océaniques". Université de Bretagne Occidentale, 29287-Brest Cedex, France.

5 Contribution C.R.P.G. No. 823.
}

3. To identify the contribution of the different Himalayan formations and their variations with time, and thereby to constrain the uplift-erosion cycle of the Himalayas.

The 17-m.y. record is studied using the complete section of Hole $717 \mathrm{C}$ (Cores 116-717C-2H-1 to -91X-4) and the lower part of Hole $718 \mathrm{C}$, Cores 116-718C-42X-1 to -98 CC. Sediment clay mineralogy and geochemical data are on back-pocket microfiche.

\section{ANALYTICAL METHODS Mineralogy}

This research involves the analysis of 112 samples from Hole $717 \mathrm{C}$ and 38 samples from Hole $718 \mathrm{C}$. Each sample was divided into two size grades ( $>$ and $<63 \mu \mathrm{m}$ ) by sieving, with the $<63-\mu \mathrm{m}$ grade then being kept in distilled water. The fraction $>63 \mu \mathrm{m}$ was dried at low temperature (less than $40^{\circ} \mathrm{C}$ ). Mineralogical investigations are focused on the composition of the coarse minerals and of the clayey fraction; therefore, only size grades $>63 \mu \mathrm{m}$ and $<2 \mu \mathrm{m}$ have been studied.

Identification of the different lithoclastic and bioclastic phases was done under an optical microscope and by observation with a scanning electron microscope (SEM, JEOL JMS-35) at the Université de Bretagne Occidentale (Brest). Relative abundances of quartz + feldspars, micas, and sulfide aggregates were estimated. The biogenic fraction was also estimated considering, in particular, the foraminifers (well preserved or broken), the sponge spicules and the lignitic debris. Semiquantitative evaluation of the amounts of the lithoclastic fraction $>63 \mu \mathrm{m}$ were carried out by X-ray diffractometry of some samples at the Centre de Recherches Pétrographiques et Géochimiques, (Nancy, France).

The X-ray diffraction study of the fraction $<2 \mu \mathrm{m}$, performed at the Université des Sciences et Techniques de Lille, involved the analysis of 200 samples. The method of sample preparation and semiquantitative estimation is explained in Capet et al. (1990). Each sample was decarbonated in $0.2 \mathrm{~N}$ $\mathrm{HCl}$; the excess acid was removed by repeated centrifuging 


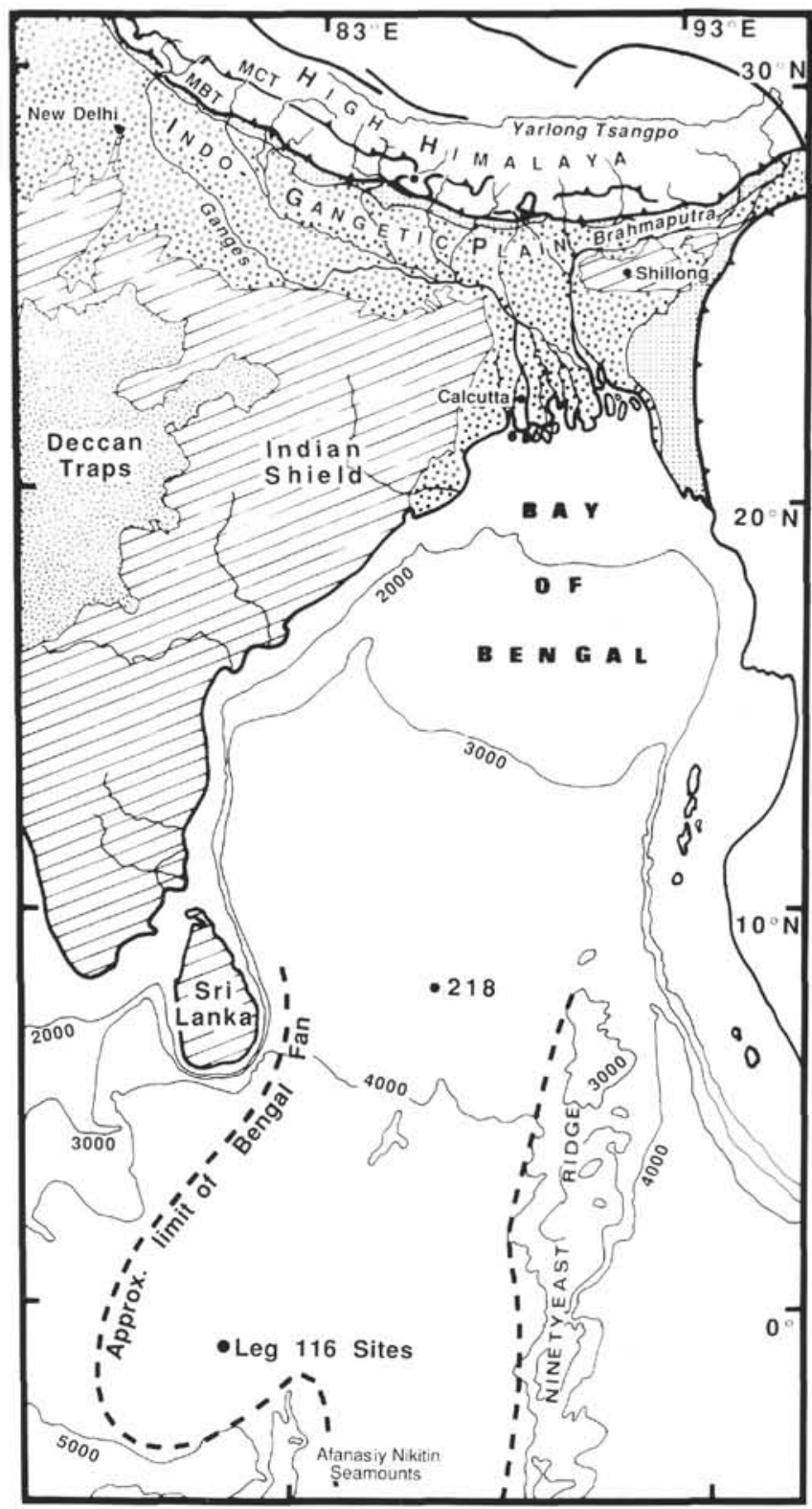

Figure 1. Map showing the location of Leg 116 Sites on the Bengal Fan and geology of the Indian peninsula. The two major Himalayan thrusts (MCT and MBT), the Himalayan hydrographic system, and the Indo-Gangetic Plain are represented.

followed by homogenization. The fraction $<2 \mu \mathrm{m}$ was collected by decantation after settling and oriented aggregates were made on glass slides. The X-ray diffractograms were made using an untreated sample, a glycolated sample, and a sample heated for $2 \mathrm{hr}$ at $490^{\circ}$. A Philips 1730 diffractometer (copper K-radiation focused by a curved quartz-crystal monochromator) was used at a scan speed of $1^{\circ} 2 \theta / \mathrm{min}$, with all instrument settings kept constant for all analyses. Semiquantitative evaluation was based on the peak heights and areas of selected clay mineral peaks, assuming that these weighted amounts added up to $100 \%$. The height of the illite and chlorite (001) peaks were taken as references. The relative proportion of smectites and mixed-layer clay minerals was determined by multiplying their peak height by a factor of 1.5 to 2 depending on their crystallinity; by contrast, well-crystallized kaolinite was corrected by a factor of 0.5 . The relative proportions of chlorite and kaolinite were determined from the ratio of peak heights (respectively $3.54 \AA$ and $3.58 \AA$ ): when this ratio is 1 , the amount of chlorite is assumed to be twice that of kaolinite. Final data are given in percent, the relative error being about $\pm 5 \%$ (Holtzapffel, 1985). The values of illite crystallinity correspond to the $1 / 10 \theta$ breadth of the $10-\AA$ peak at half height. This measurement is made on the X-ray diffractogram obtained on the glycolated sample.

For transmission electron microscopy a small volume of the fraction $<2 \mu \mathrm{m}$ was diluted in butylamine, and distilled water was added to obtain a translucent mixture. A drop of this solution was placed on a copper grid covered with a thin collodion film. The observation was done directly, without any coating, on a TEM JEOL $100 \mathrm{CX}$.

\section{Isotopic Techniques}

\section{Hydrogen and Oxygen}

Classical methods were used for quantitative extraction of structural hydrogen (Friedman, 1953) and oxygen of silicates (Clayton and Mayeda, 1963). Extraction yields were manometrically measured on $\mathrm{H}_{2}$ and $\mathrm{CO}_{2}$ gases. The $\mathrm{H}_{2}$ yield was converted to the $\mathrm{H}_{2} \mathrm{O}^{+}$content of the sample. Isotopic ratios $\left(\mathrm{D} / \mathrm{H},{ }^{18} \mathrm{O} /{ }^{16} \mathrm{O}\right)$ were measured on $\mathrm{H}_{2}$ and $\mathrm{CO}_{2}$ gases using a VG $602 \mathrm{D}$ mass spectrometer. Results are expressed in $\delta$ notation relative to standard mean ocean water (SMOW). For NBS-28, $\delta^{18} \mathrm{O}=9.60 \%$. Reproducibility for standards and duplicates is $\pm 2 \%$ o for $\delta \mathrm{D}$ and $\pm 0.2 \%$ o for $\delta^{18} \mathrm{O}$. However, some samples containing $\approx 2 \mathrm{wt} \%$ of organic carbon have a reproducibility of $\pm 1 \%$ for $\delta^{18} \mathrm{O}$ (see Table 2 ).

Mineral phases were separated using both magnetic and gravimetric techniques. Quartz fractions were leached with HF $20 \%$ for $1 \mathrm{hr}$ to remove all feldspars. Under such conditions yields of extractions were between 99 and 100\% compared to pure quartz. Following the method of Savin and Epstein (1970a), clayey fractions were placed in an atmosphere dried by $\mathrm{Ti}_{2} \mathrm{O}_{5}$ for at least 1 day to remove absorbed and interlayer water.

\section{Strontium and Neodymium}

Analytical techniques for $\mathrm{Rb}-\mathrm{Sr}$ runs have been described elsewhere (Alibert et al., 1983). For Sm-Nd runs a method developed for sediments and granitic rocks (Boher et al., unpubl. data) was used: one part of sample powder $(\approx 100 \mathrm{mg})$ is mixed with three parts of pure lithium metaborite. The mixture is transferred into a platinum-gold-iridium crucible, to which weighted spikes are added, and dried slowly overnight. After melting, the glass is dissolved in $1 \mathrm{~N} \mathrm{HCl}$ and rare-earth elements (REE) coprecipitated with iron hydroxide. Fe and $\mathrm{REE}$ are shared by anionic resin in concentrated $\mathrm{HCl}$. The subsequent steps for $\mathrm{Sm}-\mathrm{Nd}$ separation are described in Michard et al., (1985).

\section{MINERALOGY}

\section{Clay Mineralogy}

In all samples the fraction $<2 \mu \mathrm{m}$ always contains chlorite, illite, mixed layers, smectites, and kaolinite in various amounts. In general the nature of each of these minerals does not change with depth.

\section{Illite and Chlorite}

These appear on tunneling electron microscope (TEM JEOL 100CX) photomicrographs as large, sharp-edged particles. They often show a watered-looking surface (Beutelspacher and Van Der Marel, 1968). In clayey and biogenic levels their sizes decrease and they have irregular edges (Figs. $2 \mathrm{~A}$ and $2 \mathrm{~B}, 3 \mathrm{~A}$ and $3 \mathrm{~B}$ ). 


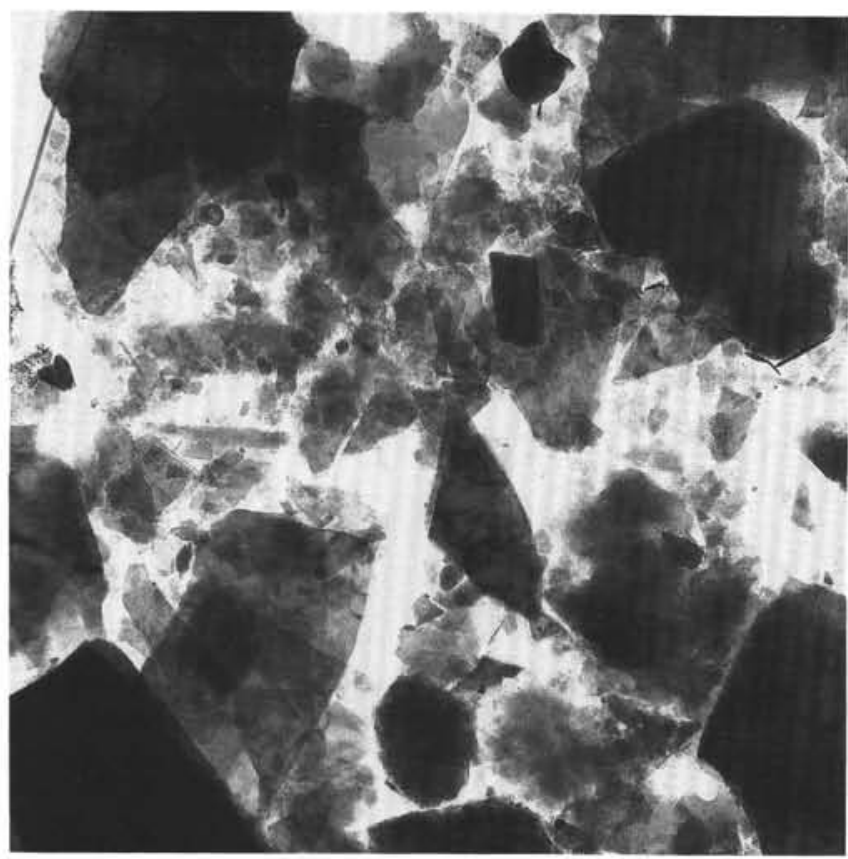

A

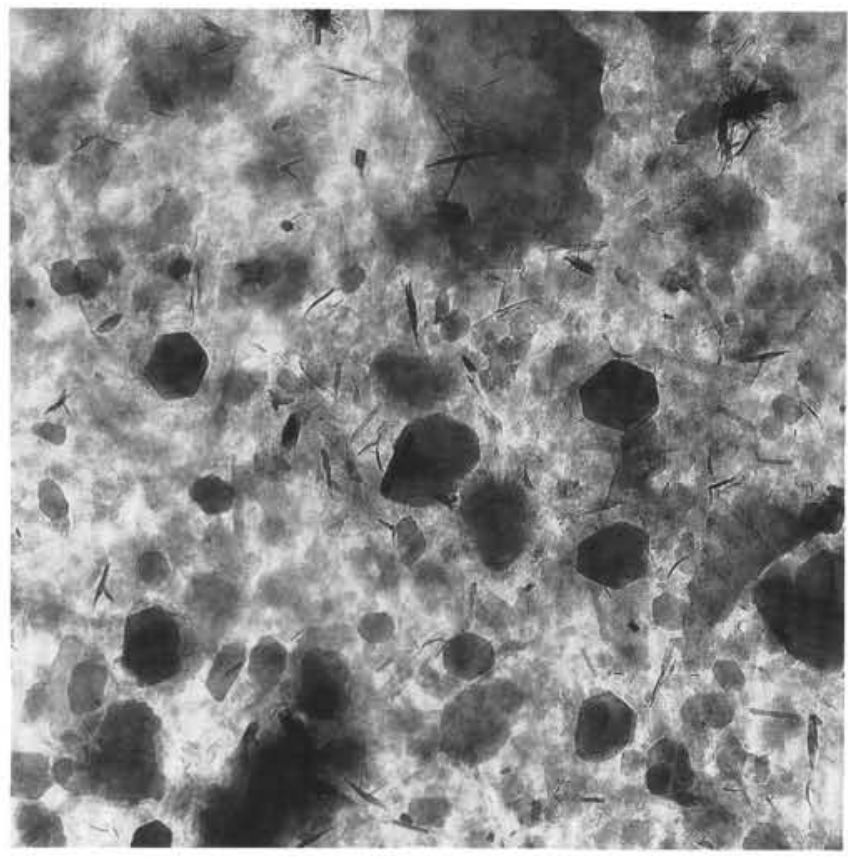

C

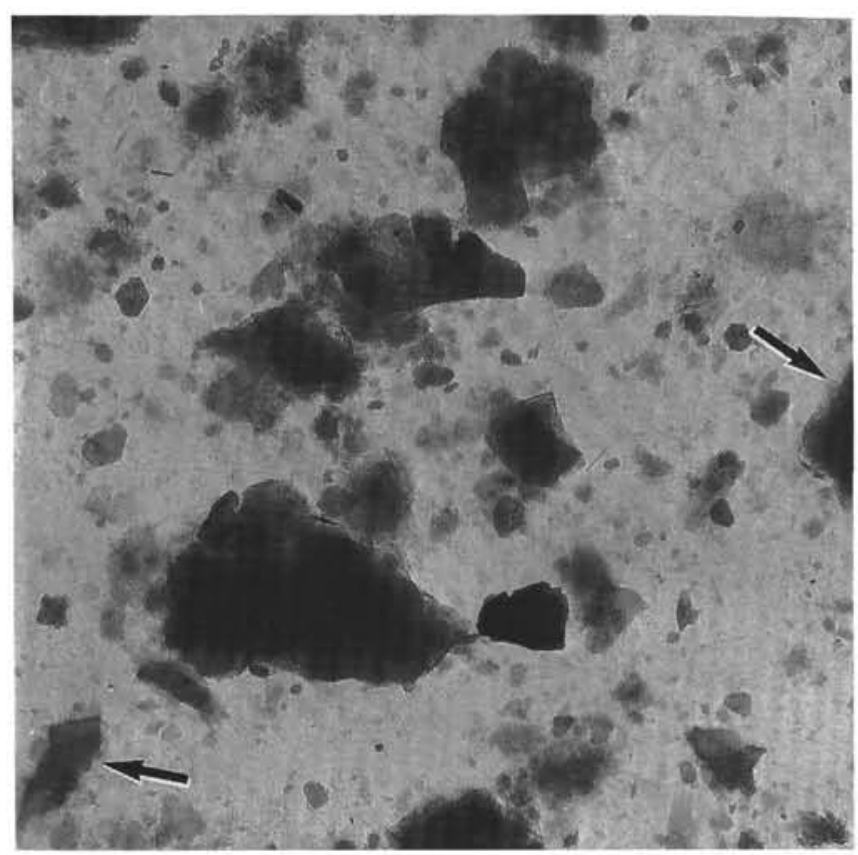

B

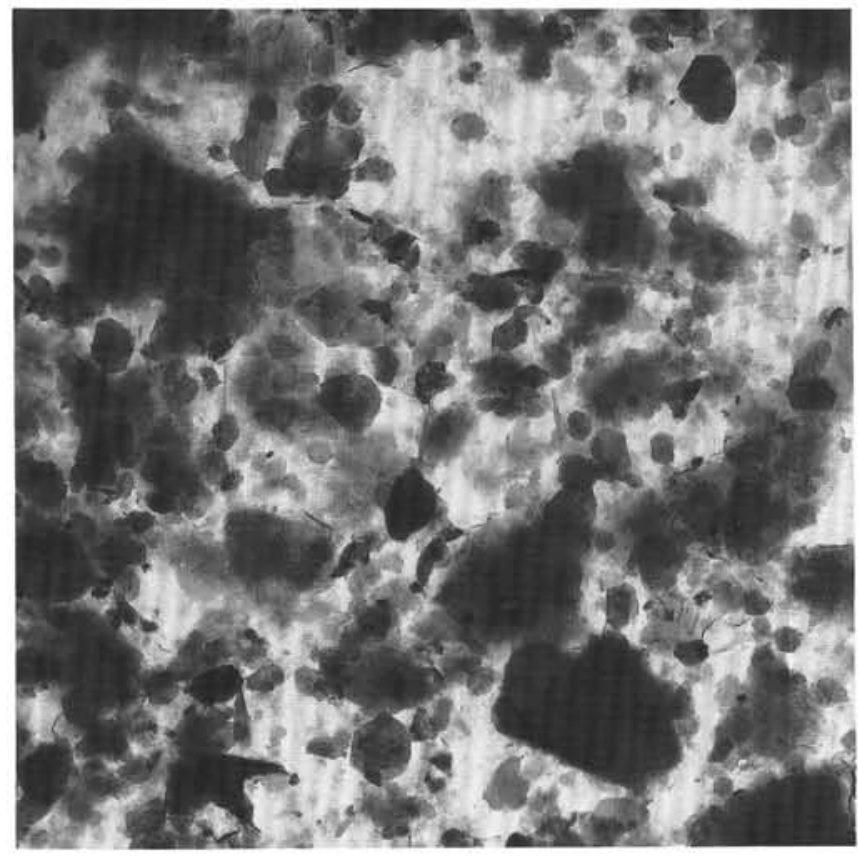

D

Figure 2. Transmission electron microscopy (TEM) photomicrographs of clay assemblages. A. Sample 116-717C-81X-CC (29-30 cm), Zone 3 . Well-preserved illites and chlorites associated with small fleecy smectites and rare kaolinites $(\times 15000)$. B. Sample $116-717 \mathrm{C}-48 \mathrm{X}-1,42-43 \mathrm{~cm}$, Zone 3. Dominant illites and chlorites showing light overgrowths of laths (arrows). Smectites and kaolinites are more abundant than in the previous sample $(\times 15000)$. C. Sample 116-718C-72X-6, 93-94 cm, Zone 3. Large amounts of small sub-hexagonal kaolinite; appearance of needles of goethite. Other clays are smectites and rare illites. D. Sample 116-718C-78X-4, 14-15 cm, Zone 3. Same characteristics as C, except that goethite is absent $(\times 15000)$.

\section{Mixed Layer Clays}

These are diversified, random, and present in essentially constant proportions $(\approx 15 \%)$. Particular mixed-layer clays are sometimes encountered in parts of the section, showing evidence of illite and vermiculite layers with few smectite layers (for example Sample, 116-717C-38X-1, 69-70 cm (Fig. 4).

\section{Smectites}

These appear as small fleecy particles (Figs. 3B and 3D).

\section{Kaolinites}

These appear as small, well-preserved particles, in most cases showing typical pseudo-hexagonal forms (Figs. $2 \mathrm{C}$ and 2D). 

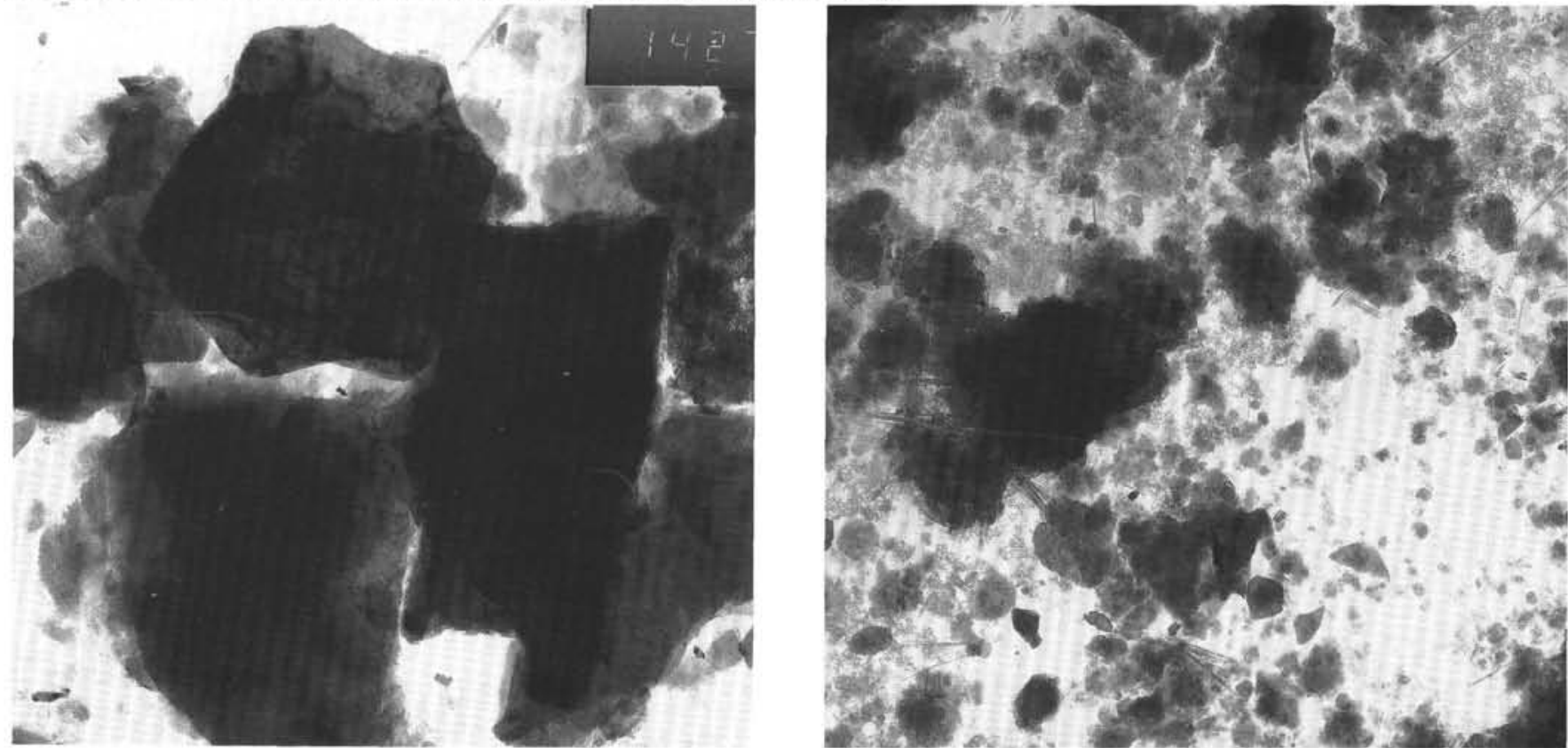

A

$15 \mu \mathrm{m}$

B

$15 \mu \mathrm{m}$
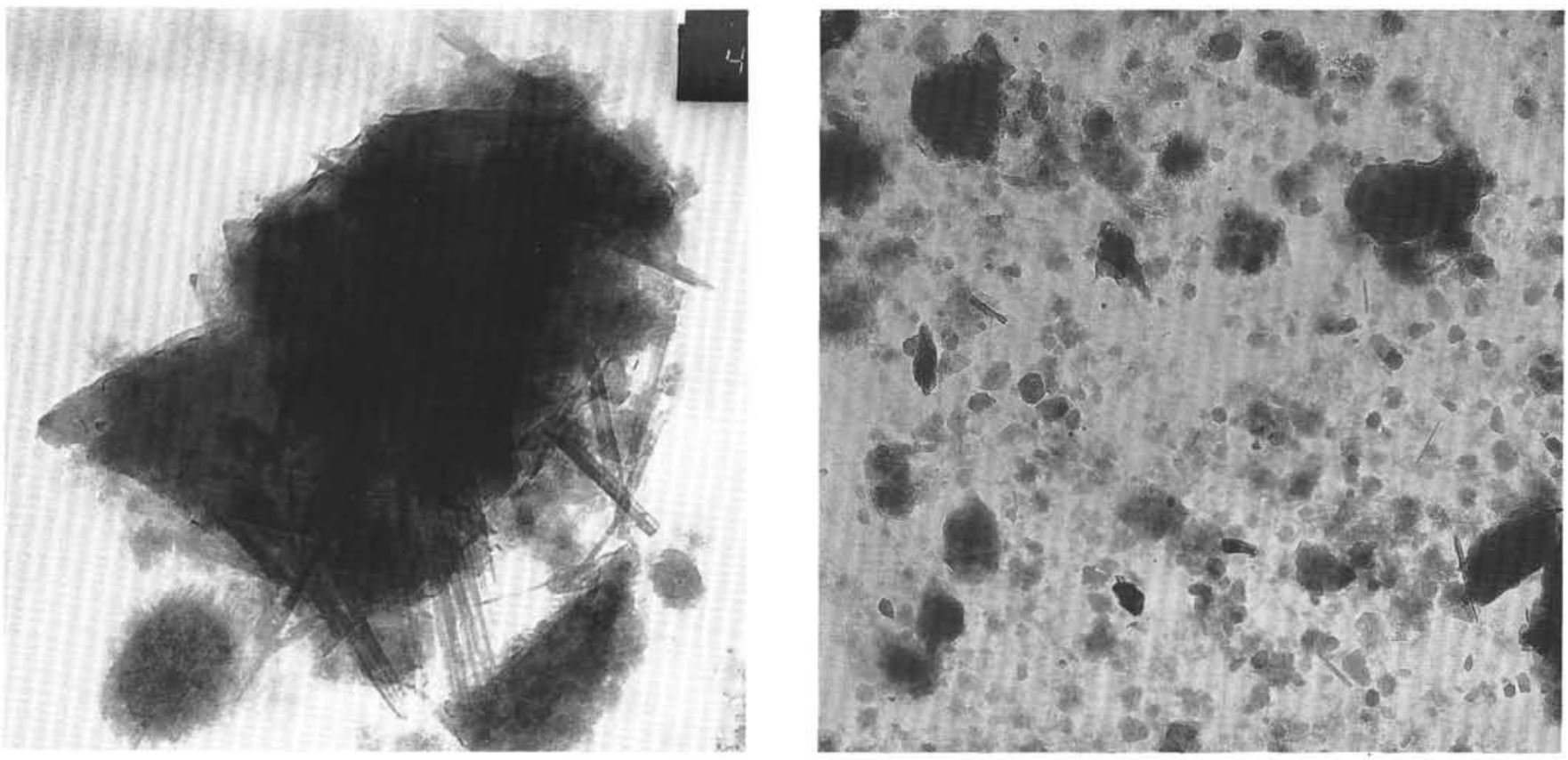

C

$28.5 \mu \mathrm{m}$

$15 \mu \mathrm{m}$

Figure 3. TEM photomicrographs of clay assemblages. A. Sample 116-717C-4X-1, 23-24 cm, Zone 1. Well-preserved illites and chlorites showing a typical water-like surface and sharp edges $(\times 21000)$. B. Sample 116-717C-22X-4, 100-101 cm, Zone 2 . Association of small fleecy smectites with sub-hexagonal kaolinites and coarser particles of illite. Fibrous clays $(<5 \%)$ are observed $(\times 1500)$. C. Sample $116-717 \mathrm{C}-22 \mathrm{X}-4,100-101 \mathrm{~cm}$, Zone 2. Flakes of fibrous clay (probably palygorskyte). The tips of the fibers are often broken, suggesting an aeolian transport. D. Sample 116-717C-65X-3, 29-30 cm, Zone 3. Fleecy kaolinites associated with rare illites. Note that the outlines of the illites seem more altered than in photograph A.

In spite of the maximum depth reached ( $935 \mathrm{mbsf})$, very little evidence of burial diagenesis has been recognized. Smectite minerals that are unstable in burial conditions (Dunoyer de Segonzac, 1969), exist even in the oldest sediments. Moreover, the crystallinity index of illite, one of the more accurate parameters for indicating diagenesis, does not significantly vary downhole (Table 1). Therefore the clay assemblages reflect initial sedimentary composition and environmental conditions from lower Miocene to the Present.

\section{Mineral Assemblages}

The analysis of both the petrographic characters (Shipboard Scientific Party, 1989) and the mineralogical compositions of the fraction $<2 \mu \mathrm{m}$ (Figs. 5, 6, and 7) reveal that, in 


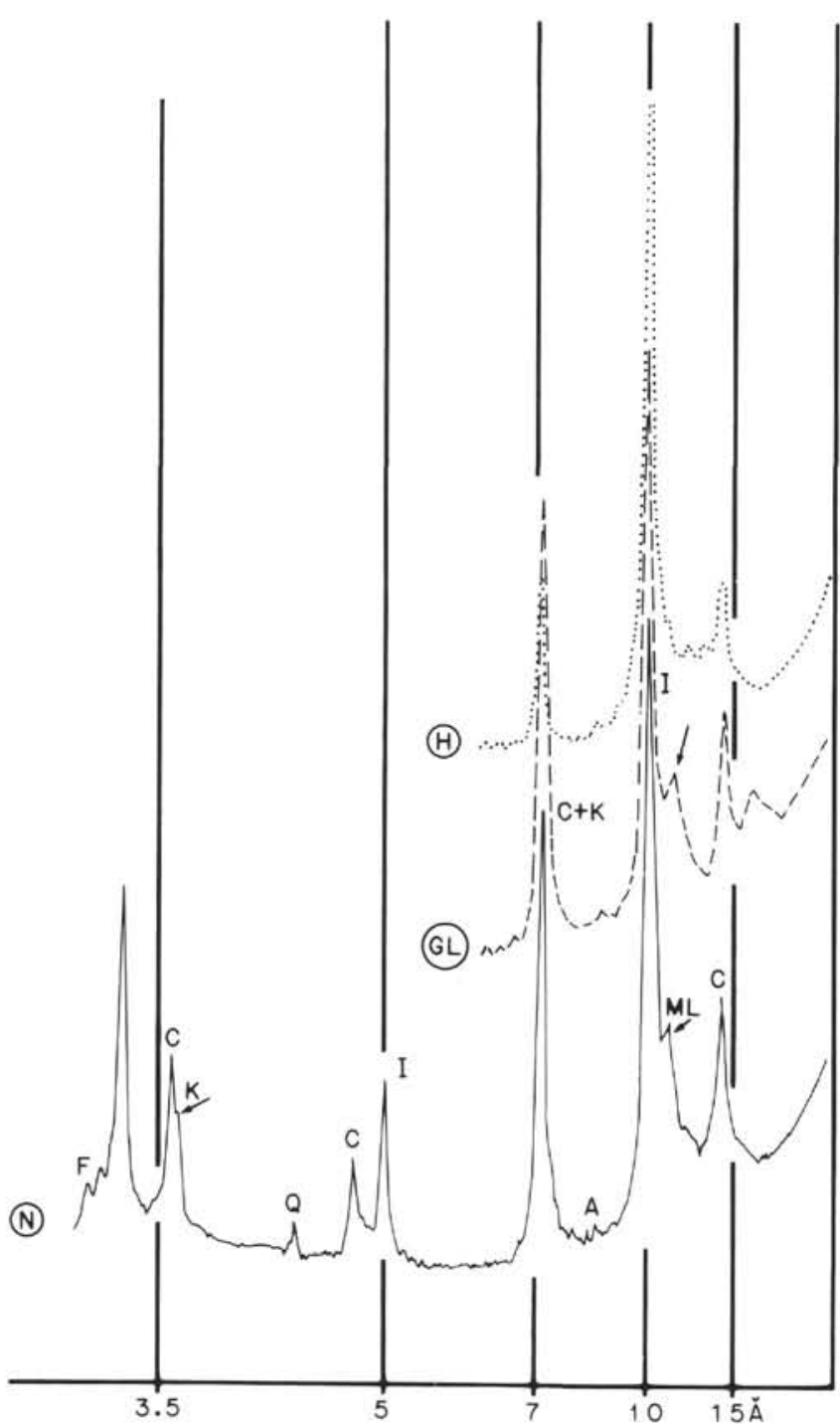

Figure 4. Diffractogram of Sample 116-717C-38X-1, 69-71 cm, showing sub-regular mixed-layer clays (ML). N: natural unheated test, GL: glycolated test, $\mathrm{H}$ : heated test, I: illite, C: chlorite, K: kaolinite, A: amphibole, Q: quartz, F: feldspars.

the silty or sandy levels, illites and chlorite represent $45 \%$ to $85 \%$ of the clayey fraction. In contrast, smectite and kaolinite are dominant $(50 \%$ to $85 \%)$ in biogenic-rich clays and in claystones. This relationship is well documented all over the Ganges and Indus fans (Bouquillon et al., 1988; Debrabant et al., unpubl.data). Therefore it is possible to define two types of levels based on the mineralogical composition of the clay fraction: (a) ICRA levels for illite- and chlorite-rich assemblages (more than $50 \% \mathrm{I}+\mathrm{C}$ ), that are composed of sandy and silty sediments; (b) SK-rich assemblages levels for Smectiteand Kaolinite-rich assemblages (more than $50 \% \mathrm{~S}+\mathrm{K}$ ), which are composed of claystone and carbonaceous oozes.

From the relative abundance of ICRA and SKRA levels (Figs. 5 and 6; Table 1), the sequences represented by Hole $717 \mathrm{C}$ and the base of Hole $718 \mathrm{C}$ are divided into three zones:

1. Zone 3 from middle-early Miocene to late Miocene (17.1 to $\approx 6 \mathrm{~m} . \mathrm{y}$.) is largely dominated by ICRA silts and sands. Cores $116-718 \mathrm{C}-98 \mathrm{X}$ to $-42 \mathrm{X}$ and $116-717 \mathrm{C}-91 \mathrm{X}$ to $-59 \mathrm{X}$. Depth: $718 \mathrm{C}, 935$ to $408 \mathrm{mbsf}$; $717 \mathrm{C}, 828$ to $530 \mathrm{mbsf}$.
Table 1. Relative abundance $(\%)$ of the different clay species in the fraction $<2$ $\mu \mathrm{m}$, and Illite crystallinity in the different zones.

\begin{tabular}{lccccc}
\hline & $\begin{array}{c}\text { Number of } \\
\text { samples }\end{array}$ & $\begin{array}{c}\text { Smectite } \\
+ \text { Kaolinite }\end{array}$ & $\begin{array}{c}\text { Illite } \\
+ \text { chlorite }\end{array}$ & $\begin{array}{c}\text { Mixed } \\
\text { layers }\end{array}$ & $\begin{array}{c}\text { Illite } \\
\text { crystallinity } \\
\text { index 0.12 } \theta\end{array}$ \\
\hline Zone 1 & 10 & 30 & 55 & 15 & 3.6 \\
Zone 2 & 55 & 65 & 20 & 15 & 4.1 \\
Zone 3 717C & 35 & 30 & 60 & 10 & 3.1 \\
Zone 3 718C & 35 & 30 & 60 & 10 & 3.1 \\
\hline
\end{tabular}

2. Zone 2 from late Miocene to late Pleistocene $(\approx 6$ to $\approx 0.8 \mathrm{~m} . \mathrm{y}$.) is dominated by SKRA with frequent ICRA intercalations (26\%). Cores 116-717C-60X to -21X. Depth: 530 to 160 mbsf.

3. Zone 1 from late Pleistocene to Holocene $(\approx 0.8$ ? m.y. to present) is dominated by ICRA levels $(84 \%)$. Cores 116$717 \mathrm{C}-21 \mathrm{X}$ to $-4 \mathrm{X}$. Depth: 160 to $0 \mathrm{mbsf}$ ).

Zone 3: Cores 116-718C-98X to -42X and 116-717C-91X to $59 \mathrm{X}$

This zone is largely dominated by turbiditic sediments. 59 samples are silty or sandy ICRA levels. In ICRA levels chlorite and illite represent about $65 \%$ of the total fraction $<2$ $\mu \mathrm{m}$ (Figs. 2A and 2B). Most common non-clay minerals of the fractions $<2 \mu \mathrm{m}$ are quartz and feldspars with sporadic amphiboles and traces of goethite.

The fractions $>63 \mu \mathrm{m}$ are composed of biogenic material and detrital minerals. In samples from Cores 116-718C-98X to $-42 \mathrm{X}$, lignitic debris is present in low to medium abundance throughout the zone. Foraminifers are present sporadically. From Cores 116-717C-91X to $-59 \mathrm{X}$, the biogenic fraction is rare with local occurrence of well-preserved or broken foraminifers generally associated with scarce sponge spicules. Lignitic fragments may be locally abundant with debris up to $400 \mu \mathrm{m}$ in size. The detrital minerals are quartz, feldspar, and micas in highly variable proportions (Fig. 8D). The quartz is often hyaline and angular to subangular; some crystals are up to $500 \mu \mathrm{m}$ in size. The phyllites are mainly composed of flakes of muscovite, biotite and chlorite. Rounded, translucent, pink garnet has been found in Samples 116-718C-91X-1, 60-61 cm, $-717 \mathrm{C}-90 \mathrm{X}-2,8-9 \mathrm{~cm},-717 \mathrm{C}-66 \mathrm{X}-2,137-139 \mathrm{~cm}$, and $-717 \mathrm{C}$ $69 \mathrm{X}-1,71-72 \mathrm{~cm}$.

Some minor sequences of finer clayey or calcareous materials are interbedded with the silty and sandy turbidites. In these SKRA samples, chlorite disappears and smectite and kaolinite represent $\approx 66 \%$ of the clayey fraction. In Hole $718 \mathrm{C}$, two zones of reddish material (116-718C-78X-4, 14--16 cm, and $-72 X-6,93-95 \mathrm{~cm})$ are enriched in kaolinite $(25 \%$ and $30 \%$ ) in the form of small pseudo-hexagonal particles related to needles of goethite (Figs. 2C and 2D). Sample 116-717C$65 \mathrm{X}-3,29-31 \mathrm{~cm}$, contains large amounts of carbonates. The clay assemblage is dominated by smectite $(\approx 65 \%)$ and kaolinite $(\approx 15 \%)$. Smectite is always fleecy and kaolinites often present a typical pseudo-hexagonal form. The illites from these facies show distinct signs of slight alteration (Fig. 3D). In the deep part of Holes $717 \mathrm{C}$ and $718 \mathrm{C}$ (Cores 116-717C$9 \mathrm{OX}$ to $-718 \mathrm{C}-88 \mathrm{X}$ ), lath-shaped clays are present with little needles developed around the particles in three directions at $60^{\circ}$, indicating incipient early diagenesis (Fig. 2B).

\section{Zone 2: Cores 116-717C-60X to $-21 \mathrm{X}$}

This zone is characterized by an alternation of SKRA and ICRA levels. Of the 57 analyzed samples of Zone 2, 42 belong to SKRA and 15 to ICRA. Generally, clays and calcareous clays contain kaolinite and smectite whereas silty or sandy samples contain illite and chlorite. ICRA levels are less enriched in illite and chlorite than those of Zone 3. Except for 


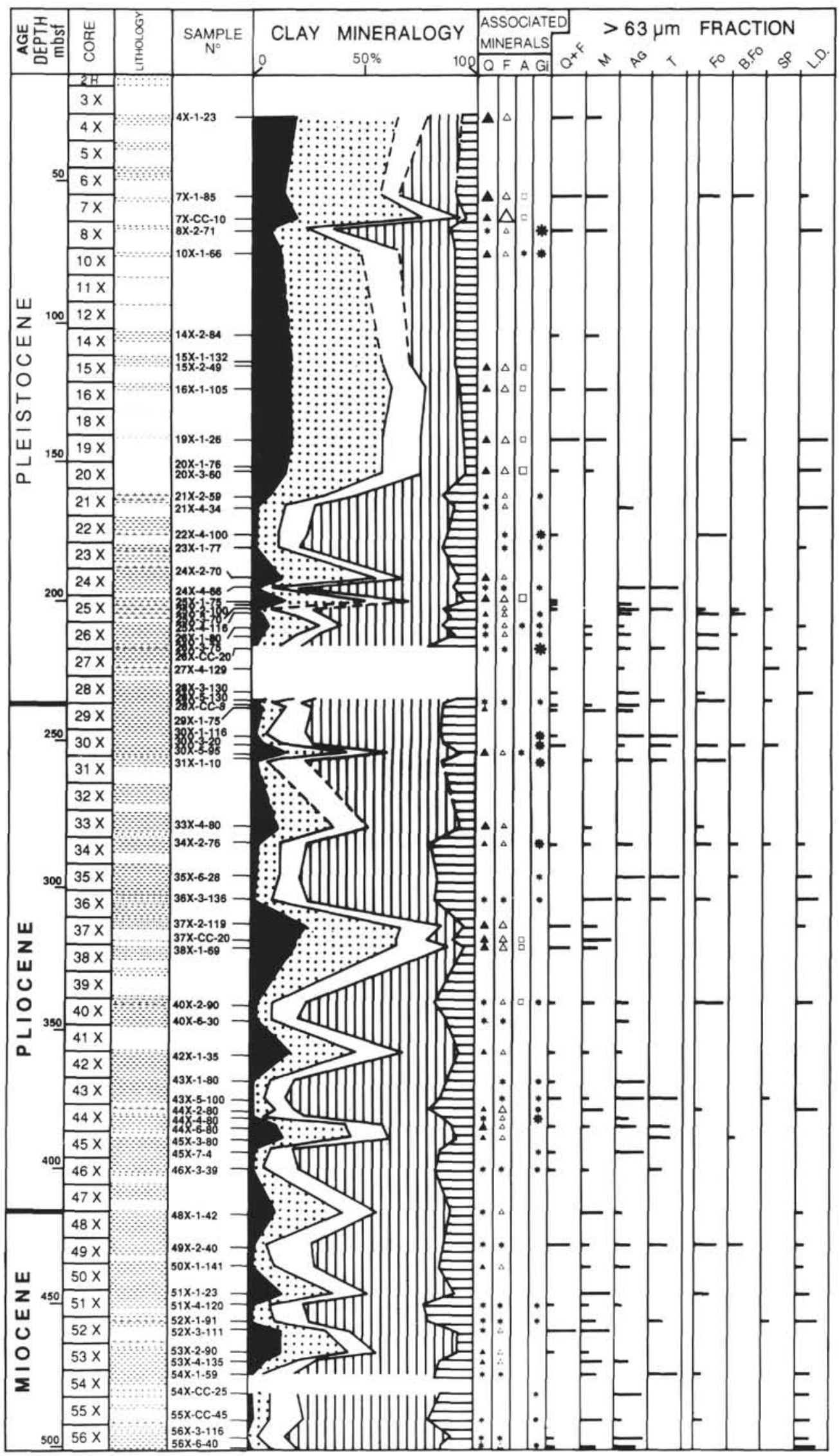

Figure 5. Summarized clay fraction and fraction $>63 \mu \mathrm{m}$ in Hole $717 \mathrm{C}$ (see legend on Fig. 7). 


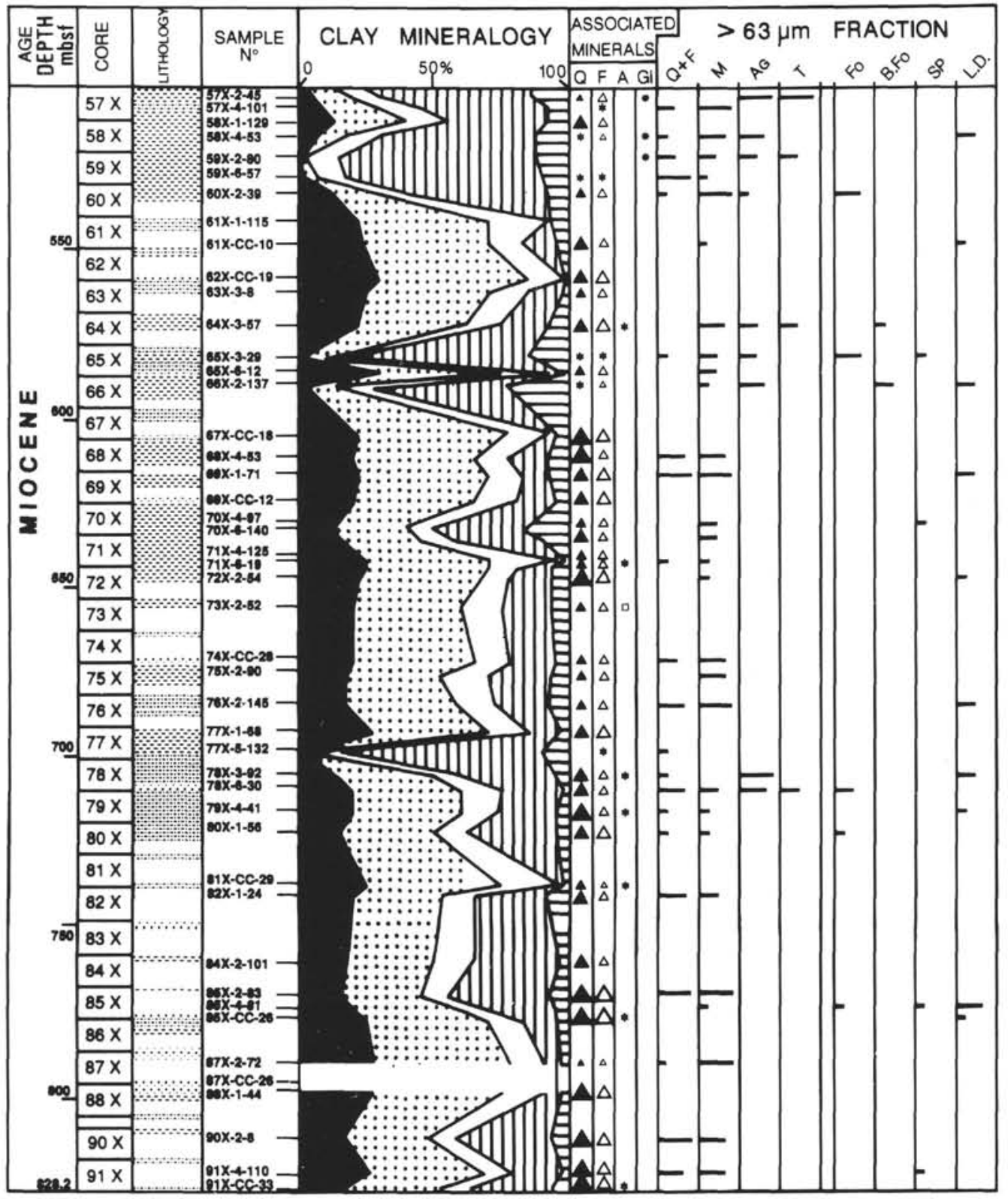

Figure 5 (continued).

the Samples 116-717C-37X-2, 119-120 cm, to $-38 X-1,69-70$ $\mathrm{cm}$, where particular mixed-layer clays are encountered with $65 \%$ of illite + chlorite, the fraction of illite and chlorite never exceeds 0.50 . However the mean fraction in Zones 1 and 3 is 0.63 for ICRA. Compared with Zone 3 , the fraction $<2 \mu \mathrm{m}$ is poor in quartz and feldspar and SKRA levels are slightly enriched in gibbsite. TEM observations show fleecy smectites, hexagonal kaolinites and illites, and rare palygorskite in short fibers (Sample 116-717C-22X-4, 100-102 cm, Figs. 3B and $3 \mathrm{C}$ ). The palygorskite occurs either isolated or assembled in flakes with the extremity of the fibers often broken. This mineral forms less than $5 \%$ of the fraction $<2 \mu \mathrm{m}$ in all samples, as it has never been identified with X-ray diffraction methods.

The lithoclastic fraction $>63 \mu \mathrm{m}$ is less well represented in this zone. According to Shipboard Scientific Party (1989), maximum grain size is significantly lower than in Zones 1 and 3. Muscovite and biotite of small size $(100-300 \mu \mathrm{m})$ are predominant and in some cases forms the whole lithoclastic fraction $>63 \mu \mathrm{m}$. The chlorite fraction is rare and generally large $(400-1000 \mu \mathrm{m})$. Quartz and feldspars are always present but not very abundant except in some ICRA levels. Quartz grains are hyaline, angular to subangular, and of small size $(100-200 \mu \mathrm{m})$. Amphibole and tourmaline are locally present. Sulfide aggregates (100-2500 $\mu \mathrm{m}$ long) are frequent and locally form nearly the whole of the fraction $>63 \mu \mathrm{m}$. Pyritic tubes up to several $\mathrm{mm}$ long and $1 \mathrm{~mm}$ in diameter are sometimes very abundant and associated with aggregates (Fig. 8C).

The bioclastic fraction $>63 \mu \mathrm{m}$ is more abundant in Zone 2 than in the other zones. It may form up to $50 \%$ of the fraction $>63 \mu \mathrm{m}$. Lignitic debris is common, especially between Cores 116-717C-46X and -58X. Well-preserved or broken foraminifers are also more abundant than in Zones 1 and 3, and their occurrences are linked to the presence of lignitic debris. Well-preserved foraminifers (Figs. 8A and 8B) are abundant in 


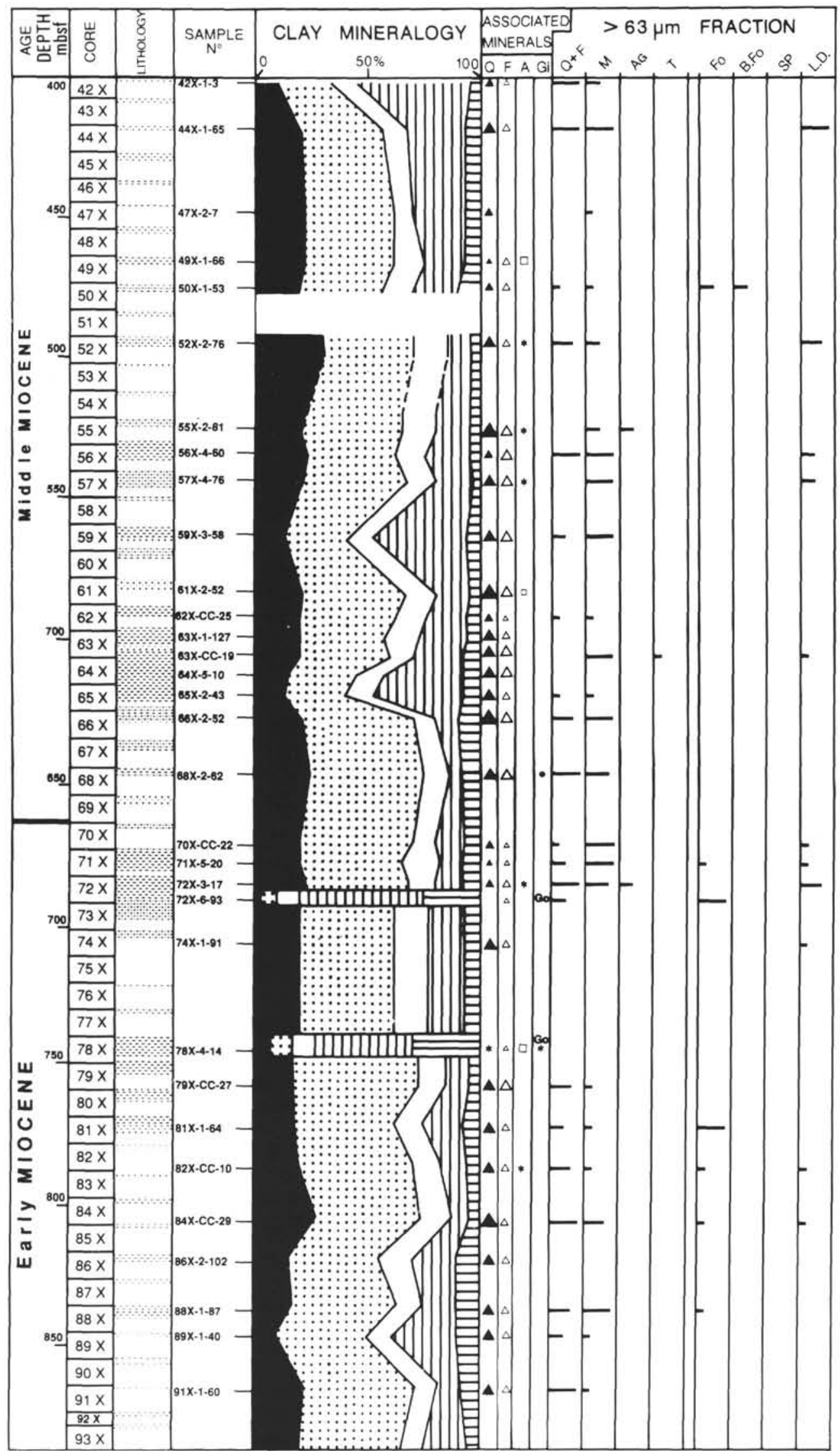

Figure 6. Summarized clay fraction and fraction $>63 \mu \mathrm{m}$ in Hole $718 \mathrm{C}$ between Cores $42 \mathrm{X}$ and $98 \mathrm{X}$ (see legend on Fig. 7). 


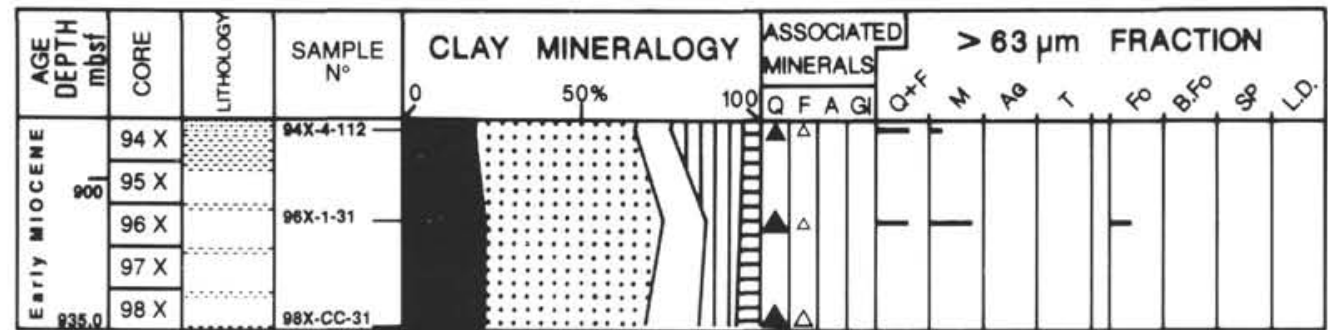

Figure 6 (continued).

the upper part of Zone 2 (Cores 116-717C-22X to -37X) where they are associated with sponge spicules. The abundance of bioclastic material in Zone 2 is also shown by the organic carbon content that averages about $1.5 \%$, whereas in Zone 3 it is $\approx 0.4 \%$ (Shipboard Scientific Party, 1989).

\section{Zone 1: 116-717C-21X to $-4 \mathrm{X}$}

Zone 1 shows a clear return to silty and sandy ICRA levels. The mineralogical features of this zone are similar to those of Zone 3 (Figs, 3A and 3B). In the fraction $>63 \mu \mathrm{m}$, phyllites and quartz + feldspar are in equal proportions. In the upper zone of Cores 116-717C-8X to $-4 \mathrm{X}$, as well as between Cores 116-717C-19X and -21X, lignitic debris is abundant.

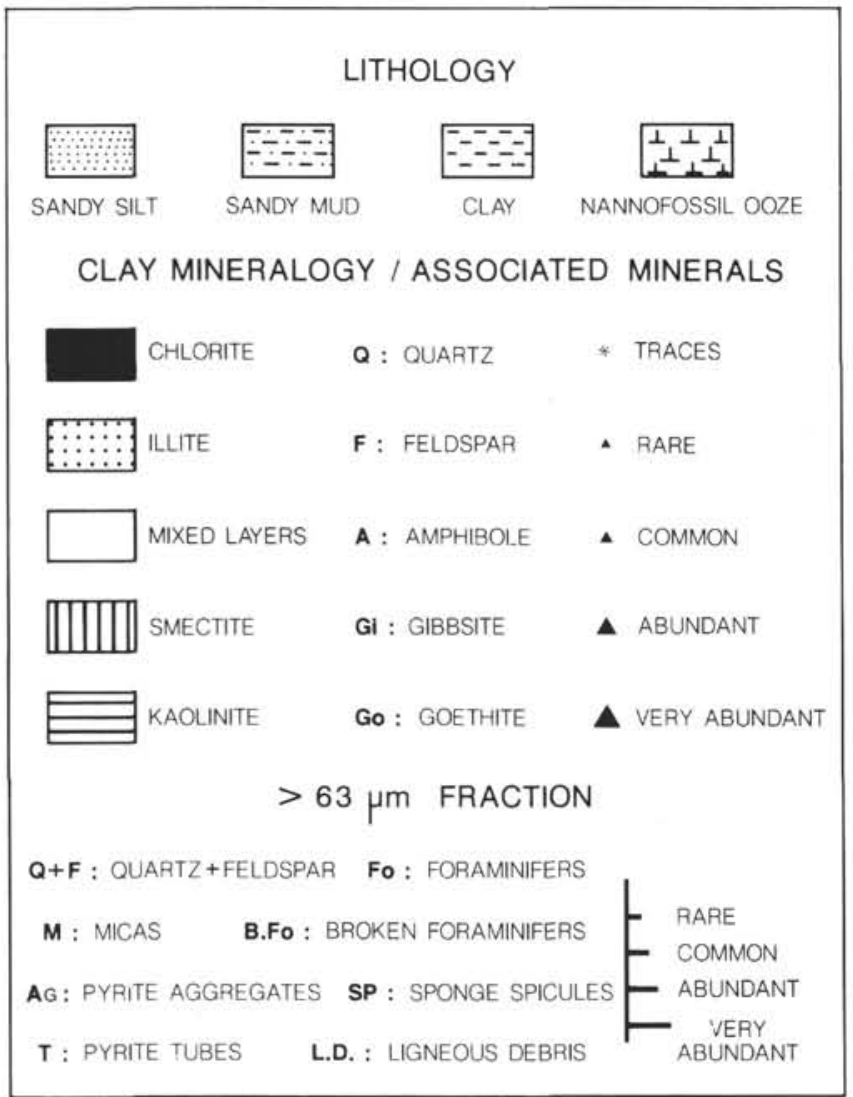

Figure 7. Graphic symbols used for lithologic descriptions for the fraction $<2 \mu \mathrm{m}$ (clay and associated minerals) and for the fraction $>63$ $\mu \mathrm{m}$ (relative abundance of lithoclasts and bioclasts).

\section{Isotopic Results}

Isotopic measurements have been done for hydrogen, oxygen, strontium, and neodymium. As analyses had to be carried out on separated mineral fractions, samples rich in the coarse grain fraction $(>63 \mu \mathrm{m})$ were preferentially selected.
Hence the samples are not representative of all the facies; for instance, levels from Zone 2 have not been analyzed. From previous work on sediments, $\delta \mathrm{D}$ on illite and $\delta^{18} \mathrm{O}$ on quartz (Savin and Epstein, 1970a, b; Clayton et al., 1978), and Nd isotope ratios of silicate particles (Goldstein et al., 1984) are not affected during the processes of erosion, transport, and sedimentation. They are, therefore, considered to be a reliable witness of the parental rocks. On the contrary, $\mathrm{Sr}$ isotope ratios might be sensitive to exchanges with dissolved $\mathrm{Sr}$ (Goldstein, 1988).

\section{Hydrogen and Oxygen Isotopes (Table 2)}

\section{Quartz}

Ten samples of quartz separated from coarse fractions have been analyzed. $\delta^{18} \mathrm{O}$ values range from $11.7 \%$ to $13.3 \%$ with most values around $13 \%$. No variation with depth or mineralogy of samples is observed. These values are high, in the range of continental igneous rocks (e.g., Taylor and Sheppard, 1986) and typical of metamorphic rocks (e.g., 8\%o to $18 \%$ in Garlick and Epstein, 1967). However, the range of Leg 116 quartz is very narrow. The range of $\delta^{18} \mathrm{O}$ values of quartz of the High Himalaya Crystallines (Fig. 9) is similar to that of Leg 116 quartz.

\section{Micas and Chlorite}

Mixtures of biotite and chlorite separated from coarse fractions have been analyzed for $\delta^{18} \mathrm{O}$ and $\delta \mathrm{D} . \delta^{18} \mathrm{O}$ values are between $7.2 \%$ and $8.1 \%$ and $\delta \mathrm{D}$ values between -83 and $-72 \%$. Oxygen isotope fractionation between quartz and biotite-chlorite (3.6 to 5.6) are compatible with metamorphic or igneous temperatures for which biotite and chlorite are $4 \%$ to $6 \%$ depleted in ${ }^{18} \mathrm{O}$ relative to quartz (Garlick and Epstein, 1967). Two samples of muscovite have been analyzed for $\delta D$ $(-73.8 \%$ and $-73.1 \%$ ) $. \mathrm{D} / \mathrm{H}$ fractionations between muscovite and biotite-chlorite are $\approx 10$ and 0 ; both are too small for equilibrium according to the experimental data of Suzuoki and Epstein (1976) and Graham et al. (1987) (20 to 40 between $400^{\circ}$ and $800^{\circ} \mathrm{C}$ ). This could be due to mixing of distinct sources of minerals or to small degrees of hydrogen exchange during alteration or sedimentation. All $\delta \mathrm{D}$ and $\delta^{18} \mathrm{O}$ values on micas and chlorite are in the range of the High Himalaya Crystalline values (Figs. 9 and 10).

\section{Clays}

$\mathrm{H}$ - and $\mathrm{O}$-isotope compositions of fine-grained material are relatively uniform for ICRA levels $(\delta \mathrm{D}=-76 \%$ to $-72 \%$ and $\delta^{18} \mathrm{O}=12.0 \%$ to $13.0 \%$ ) but variable for SKRA levels ( $\delta \mathrm{D}=$ $-75 \%$ to $-55 \%$ and $\delta^{18} \mathrm{O}=12.5 \%$ o to $21.8 \%$ ). No systematic variation with depth is observed. On a $\delta^{18} \mathrm{O}$ vs. $\delta \mathrm{D}$ diagram (Fig. 10) these samples cover a field between the range of micas $>63 \mu \mathrm{m}$ and the field of clay minerals in equilibrium with actual Indo-Gangetic meteoric waters. ICRA samples are 


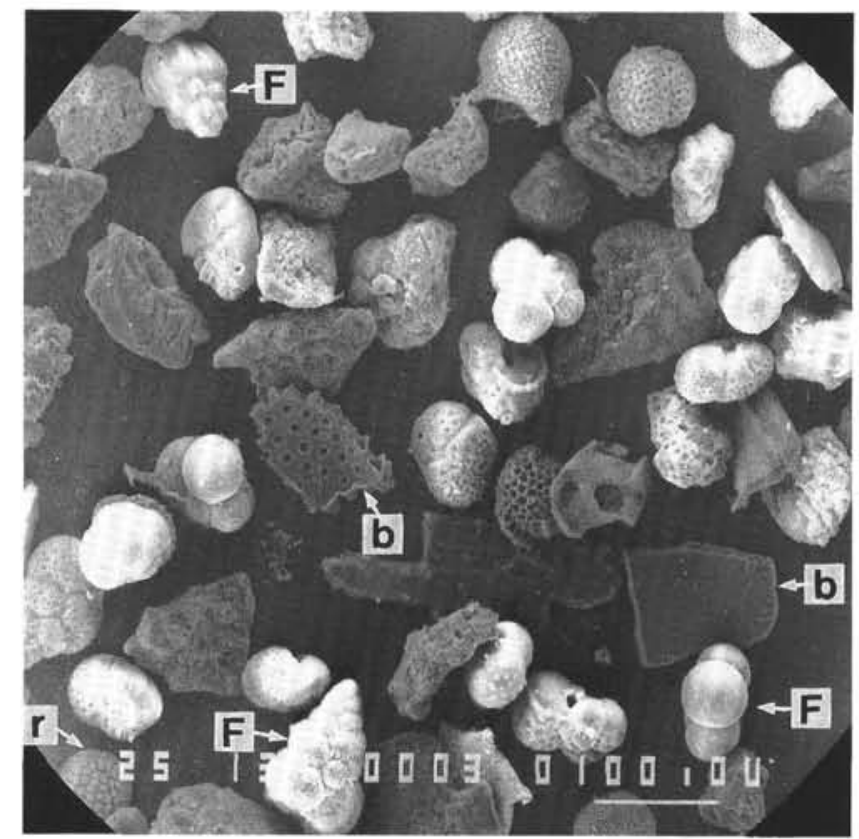

A

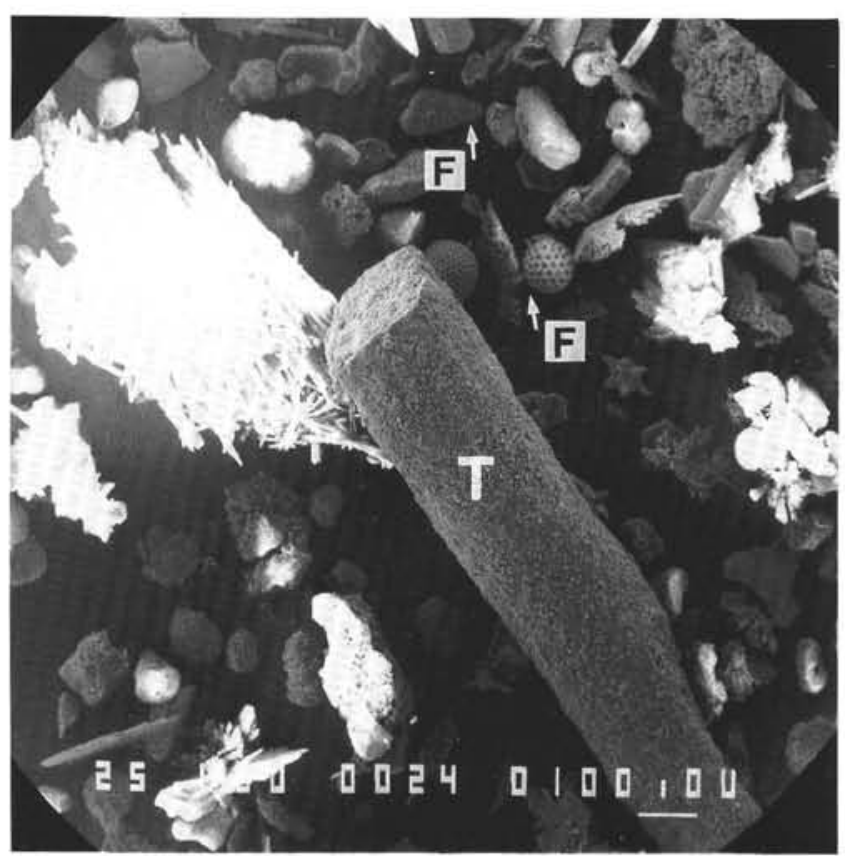

C

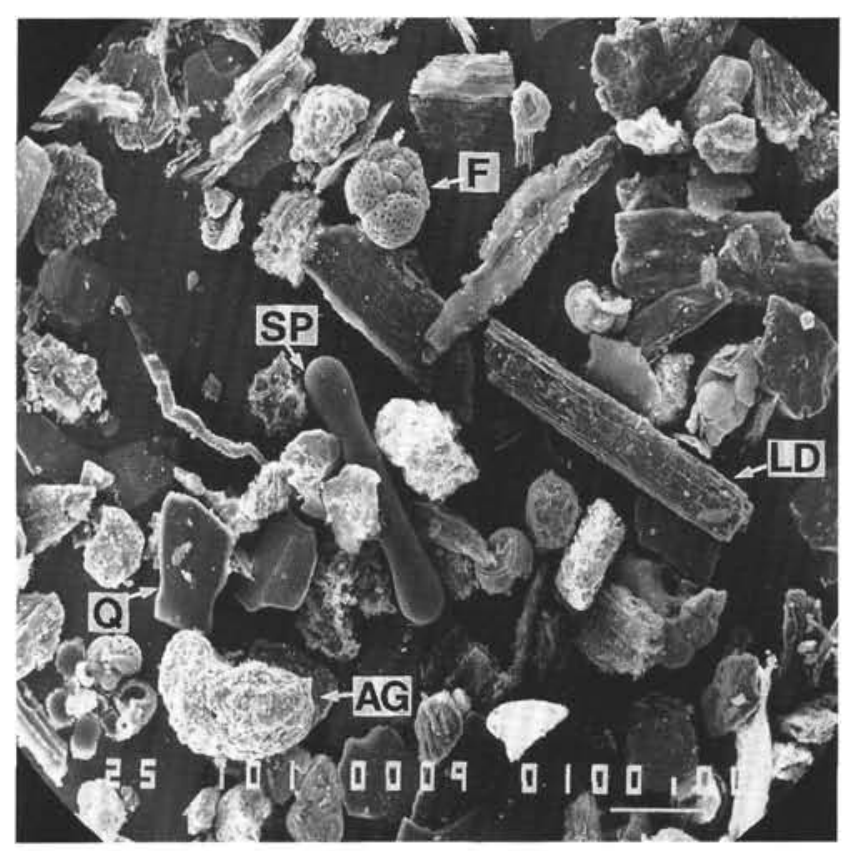

$\mathbf{B}$

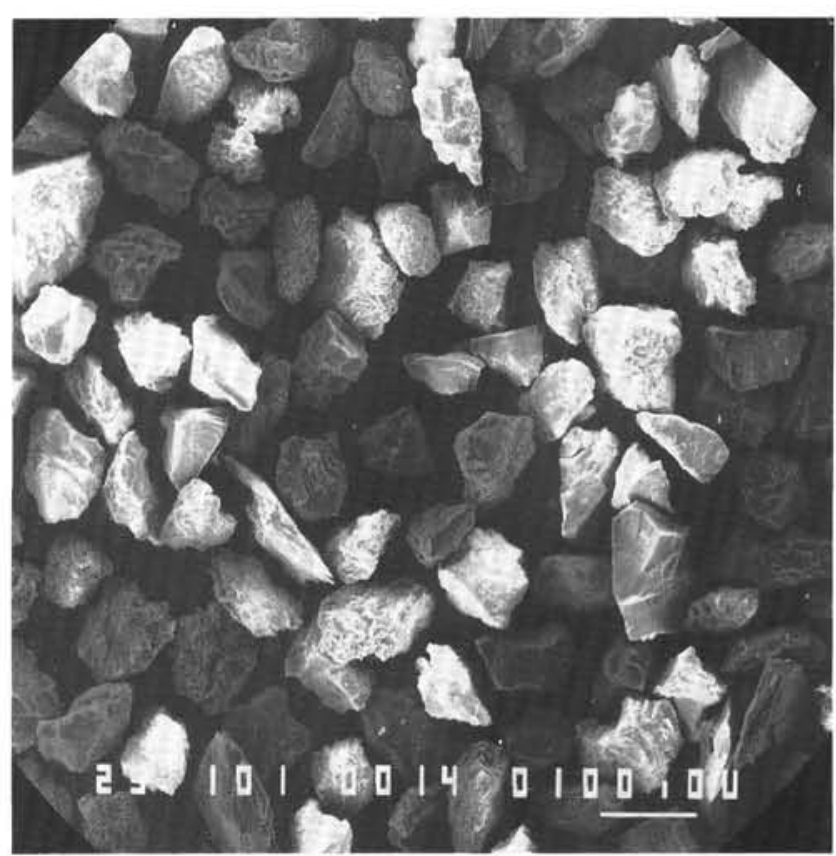

D

Figure 8. SEM photomicrographs of the fraction $>63 \mu \mathrm{m}$ from Holes $717 \mathrm{C}$ and $718 \mathrm{C}$. A. Sample 116-717C-26X-07, 20-21 cm. Well-preserved foraminifers (F), which form more than $50 \%$ of the whole fraction. Rare pyritic radiolarians ( $\mathrm{r}$ ) and undetermined bioclasts (b) are associated with small $(100 \mu \mathrm{m})$ shapeless pyrite aggregates to form the remainder of the fraction $>63 \mu \mathrm{m}$. B. Sample $116-717 \mathrm{C}-29 \mathrm{X}-1,75-76 \mathrm{~cm}$. The major part of the fraction $>63 \mu \mathrm{m}$ is formed by very abundant lignitic debris (LD) up to $300 \mu \mathrm{m}$ long, common unbroken and small foraminifers (F), and rare sponge spicules (SP). The lithoclastics are formed by common pyrite aggregates (AG) and rare angular quartz grains (Q). C. Sample $116-717 \mathrm{C}-30 \mathrm{X}-3,20-21 \mathrm{~cm}$. The lithoclastic fraction is mainly formed by large (up to $2500 \mu \mathrm{m}$ ) pyritic tubes (T) and small pyrite aggregates and quartz grains. The bioclastic fraction is mainly composed of small, unbroken, often pyritized foraminifers (F). D. Sample 116-718C-68X-2, 62-63 $\mathrm{cm}$. The whole fraction $>63 \mu \mathrm{m}$ is formed by lithoclasts mainly of angular to subangular quartz and indeterminate rock debris.

very close to the values of micas $>63 \mu \mathrm{m}$ whereas SKRA samples, except one, plot close to the line of kaolinite in equilibrium with meteoric waters (Savin and Epstein 1970c). This relation between $\mathrm{H}$ - and $\mathrm{O}$-isotope values and the mineralogical composition strongly suggests that illite and chlorite have inherited their isotopic compositions from their meta- morphic precursors. On the contrary, smectite and kaolinite produced by low-temperature continental alteration have higher $\delta \mathrm{D}$ and $\delta^{18} \mathrm{O}$ values.

The $\delta^{18} \mathrm{O}$ and $\delta \mathrm{D}$ values of the pure smectite-kaolinite fraction can be estimated by mass balance calculation assuming that illite and chlorite have preserved their original meta- 
Table 2. $\mathrm{H}, \mathrm{O}, \mathrm{Sr}$, and $\mathrm{Nd}$ isotope data and water, $\mathrm{Rb}, \mathrm{Sr}, \mathrm{Sm}$, and $\mathrm{Nd}$ content.

\begin{tabular}{|c|c|c|c|c|c|c|c|c|c|c|c|c|}
\hline $\begin{array}{l}\text { Core-Section } \\
\text { (Interval, cm) }\end{array}$ & type & $\delta \mathrm{D} \%$ & $\begin{array}{c}\mathrm{H}_{2} \mathrm{O}^{+} \\
\%\end{array}$ & $\delta_{\%}^{\delta^{18} \mathrm{O}}$ & $\begin{array}{c}\mathrm{Rb} \\
\mathrm{ppm}\end{array}$ & $\begin{array}{c}\mathrm{Sr} \\
\mathrm{ppm}\end{array}$ & ${ }^{87} \mathrm{Sr}{ }^{86} \mathrm{Sr}$ & $\underset{\mathrm{ppm}}{\mathrm{Sm}}$ & $\begin{array}{c}\mathrm{Nd} \\
\mathrm{ppm}\end{array}$ & ${ }^{143} \mathrm{Nd} /{ }^{144} \mathrm{Nd}$ & \pm & $\epsilon \mathrm{Nd}_{\mathrm{o}}$ \\
\hline \multicolumn{13}{|l|}{ HOLE $717 \mathrm{C}$} \\
\hline \multirow[t]{3}{*}{$2 \mathrm{H}-1(80-81)$} & $\begin{array}{c}<2 \mu \\
\mathrm{Q} \\
\mathrm{FK}\end{array}$ & & & 12.8 & 128 & 141 & 0.73844 & 6.36 & 32.50 & 0.511774 & 26 & -16.8 \\
\hline & $\mathrm{Bi}+\mathrm{Ch}$ & -83.5 & 6.1 & 7.2 & & & & 3.61 & 18.33 & 0.511926 & 28 & -14.0 \\
\hline & $\mathrm{Mu}+\mathrm{Q}$ & -73.8 & 1.3 & & & & & 1.66 & 8.19 & 0.511802 & 70 & -16.3 \\
\hline $7 \mathrm{X}-1(85-86)$ & $<2 \mu$ & & & 12.7 & & 222 & 0.72065 & 6.50 & 32.86 & 0.511929 & 17 & -13.8 \\
\hline $7 \mathrm{X}-\mathrm{CC}(10-11)$ & $\begin{array}{c}\mathrm{Q} \\
\mathrm{Bi}+\mathrm{Ch}\end{array}$ & -82.0 & 3.2 & $\begin{array}{r}11.7 \\
8.1\end{array}$ & & & & & & & & \\
\hline $15 X-2(49-50)$ & $<2 \mu$ & 02.0 & 3.2 & & & & & 4.65 & 23.52 & 0.511791 & 25 & -16.5 \\
\hline $19 X-C C(5-6)$ & $\begin{array}{c}<2 \mu \\
\mathrm{Q} \\
\mathrm{Bi}+\mathrm{Ch}\end{array}$ & -75.9 & 5.4 & $\begin{array}{r}12.7 \\
12.4 \\
7.7\end{array}$ & 131 & 132 & 0.74149 & 7.88 & 40.65 & 0.511817 & 27 & -16.0 \\
\hline $20 X-1(26-27)$ & $<2 \mu$ & & & & & 134 & 0.73831 & 6.47 & 33.15 & 0.511832 & 28 & -15.8 \\
\hline $24 X-4(66-67)$ & $<2 \mu$ & & & & & & & 5.70 & 27.81 & 0.511806 & 18 & -16.2 \\
\hline $26 \mathrm{X}-4(85-86)$ & $<2 \mu$ & -55.6 & 3.4 & 12.5 & & & & & & & & \\
\hline $27 X-5(70-71)$ & $<2 \mu$ & -74.3 & 5.6 & & & & & 3.52 & 18.36 & 0.511855 & 22 & -15.3 \\
\hline $29 X-5(70-71)$ & W.R. & -57.4 & 5.4 & $20.1^{*}$ & & & & & & & & \\
\hline $32 X-3(118-119)$ & W.R. & -72.0 & 6.7 & $17.7^{*}$ & & & & 5.03 & 24.00 & 0.511898 & 26 & -14.5 \\
\hline $36 \times-3(136-137)$ & $<2 \mu$ & & & & & 160 & 0.72724 & 4.80 & 22.86 & 0.511870 & 28 & -15.0 \\
\hline $41 X-C C(33-34)$ & $<2 \mu$ & & & & 165 & 116 & 0.74294 & 7.20 & 37.16 & 0.511818 & 34 & -16.0 \\
\hline $59 \mathrm{X}-6(57-58)$ & $<2 \mu$ & & & & & & & 4.76 & 22.87 & 0.511798 & 34 & -16.4 \\
\hline $61 X-1(115-116)$ & $<2 \mu$ & -76.2 & 2.2 & 12.9 & & & & 5.07 & 25.80 & 0.511788 & 30 & -16.6 \\
\hline $62 \mathrm{X}-\mathrm{CC}(25-26)$ & $\mathrm{Q}$ & & & 12.5 & & & & & & & & \\
\hline \multirow[t]{2}{*}{$65 \times-3(29-30)$} & $\begin{array}{c}<2 \mu \\
<2 \mu \text { silicate }\end{array}$ & & & & & $\begin{array}{r}910 \\
56\end{array}$ & $\begin{array}{l}0.70991 \\
0.72982\end{array}$ & 3.68 & 18.80 & 0.511679 & 22 & -18.8 \\
\hline & $<2 \mu$ carbonate & & & & & $\begin{array}{r}30 \\
1075\end{array}$ & $\begin{array}{l}0.72982 \\
0.70906\end{array}$ & & & & & \\
\hline $71 X-4(125-127)$ & $<2 \mu$ & -71.3 & 2.2 & 13.0 & & & & 4.96 & 27.17 & 0.511828 & 23 & -15.8 \\
\hline $78 \mathrm{X}-1(14-15)$ & $<2 \mu$ & -74.2 & 2.2 & & & & & & & & & \\
\hline $81 \mathrm{X}-\mathrm{CC}(29-30)$ & $<2 \mu$ & -72.5 & 2.9 & 12.0 & & & & 4.73 & 23.87 & 0.511895 & 29 & -14.5 \\
\hline \multirow[t]{2}{*}{$84 \mathrm{X}-2(101-103)$} & $\begin{array}{c}\mathrm{FK} \\
\mathrm{Q}\end{array}$ & & & 13.3 & 83 & 139 & 0.73554 & & & & & \\
\hline & $\mathrm{Bi}+\mathrm{Ch}$ & -72.5 & 3.2 & 15.3 & & & & & & & & \\
\hline $85 \mathrm{X}-2(83-84)$ & Q & & & 12.9 & & & & & & & & \\
\hline $91 X-4(110-111)$ & $\begin{array}{l}<2 \mu \\
\mathrm{Q}\end{array}$ & & & 12.3 & & & & 7.92 & 41.11 & 0.511855 & 32 & -15.3 \\
\hline \multicolumn{13}{|l|}{ HOLE $718 \mathrm{C}$} \\
\hline \multirow[t]{2}{*}{$49 X-1(66-67)$} & $\begin{array}{l}<2 \mu \\
\mathrm{Q}\end{array}$ & & & 13.3 & & & & 9.06 & 47.38 & 0.511891 & 17 & -14.6 \\
\hline & FK & & & & 43 & 104 & 0.73330 & & & & & \\
\hline $61 X-2(52-53)$ & $\begin{array}{c}\mathrm{Q} \\
\mathrm{Bi}+\mathrm{Ch}\end{array}$ & -76.9 & 70 & $\begin{array}{r}13.0 \\
9.8\end{array}$ & & & & & & & & \\
\hline $72 X-6(93-94)$ & $<2 \mu$ & -67.1 & 2.8 & 21.8 & & & & 4.88 & 25.18 & 0.511857 & 26 & -15.0 \\
\hline $78 \times-4(14-15)$ & $<2 \mu$ & & & 18.2 & & & & & & & & \\
\hline \multirow[t]{2}{*}{$79 \mathrm{X}-\mathrm{CC}(27-28)$} & $\begin{array}{l}<2 \mu \\
\mathrm{Q}\end{array}$ & & & 13.0 & & & & 5.57 & 28.80 & 0.511805 & 24 & -16.0 \\
\hline & FK & & & & 28 & 39 & 0.75999 & & & & & \\
\hline $\begin{array}{l}84 X-C C(29-30) \\
86 X-2(102-103)\end{array}$ & $<2 \mu$ & & & & & & & 5.38 & 28.00 & 0.511821 & 23 & -15.9 \\
\hline $86 \mathrm{X}-2(102-103)$ & $\begin{array}{c}\mathrm{Q} \\
\mathrm{Mu}\end{array}$ & -73.1 & 3.9 & $\begin{array}{l}13.3 \\
11.3\end{array}$ & & & & & & & & \\
\hline $96 \mathrm{X}-1(31-32)$ & $<2 \mu$ & & & & & & & 4.97 & 25.70 & 0.511744 & 44 & -17.4 \\
\hline \multicolumn{13}{|l|}{ Lesser Himalaya } \\
\hline AP 346 & W.R. & & & & & & & 8.08 & 44.00 & 0.511397 & 28 & -24.0 \\
\hline AP 385 & W.R. & & & & & & & 6.58 & 36.60 & 0.511331 & 25 & -25.0 \\
\hline \multicolumn{13}{|c|}{ High Himalaya Sedimentary Series } \\
\hline NA 178 & W.R. & & & & & & & 3.99 & 20.33 & 0.511795 & 28 & -16.4 \\
\hline NA 181 & W.R. & & & & & & & 12.61 & 58.97 & 0.512405 & 28 & -4.5 \\
\hline
\end{tabular}

*: reproducibility of $\pm 1 \%$; $<2 \mu:<2 \mu \mathrm{m}$ fraction, Q: quartz, FK: feldspars, Mu: muscovite, Bi: biotite, Ch: chlorite, W.R.: whole rock

morphic compositions (illite $10 \%$, chlorite $8 \%$ for $\delta^{18} \mathrm{O}$ and $-80 \%$ for $\delta \mathrm{D})$. Using the range of values of SKRA samples, the pure smectite-kaolinite fraction would have $\delta^{18} \mathrm{O}=18 \%$ to $23 \%$ and $\delta \mathrm{D}=-71 \%$ to $-52 \%$. Applying the $\mathrm{H}$ - and $\mathrm{O}$-isotope fractionation factors of Lawrence and Taylor (1972), Yeh and Savin (1976) and Yeh (1980), this field (Fig. 10 ) is significantly lower in $\delta \mathrm{D}$ and $\delta^{18} \mathrm{O}$ than the field for kaolinite and smectite in equilibrium with seawater. Therefore the amount of authigenic minerals, if any, cannot exceed a few percent. Meteoric water in equilibrium with these kaolinites and smectites would have $\delta^{18} \mathrm{O} \approx-4 \% o$ and $\delta \mathrm{D} \approx-22 \%$, which corresponds to the modern meteoric water in New Delhi (IAEA, 1979).

ICRA samples as well as micas and chlorite have $\delta^{18} \mathrm{O}$ values $\approx 4 \%$, lower than most detrital clays from the ocean (e.g. Savin and Epstein, 1970a). This difference emphasizes the fact that most material deposited in the Bengal Fan at Sites 717 and 718 is directly derived from a metamorphic or igneous source with no detectable effects of alteration. Also, since deposition, exchange between clays and seawater or pore water does not appear to have occurred as the mineral $\delta^{18} \mathrm{O}$ and $\delta \mathrm{D}$ values do not change with depth. 

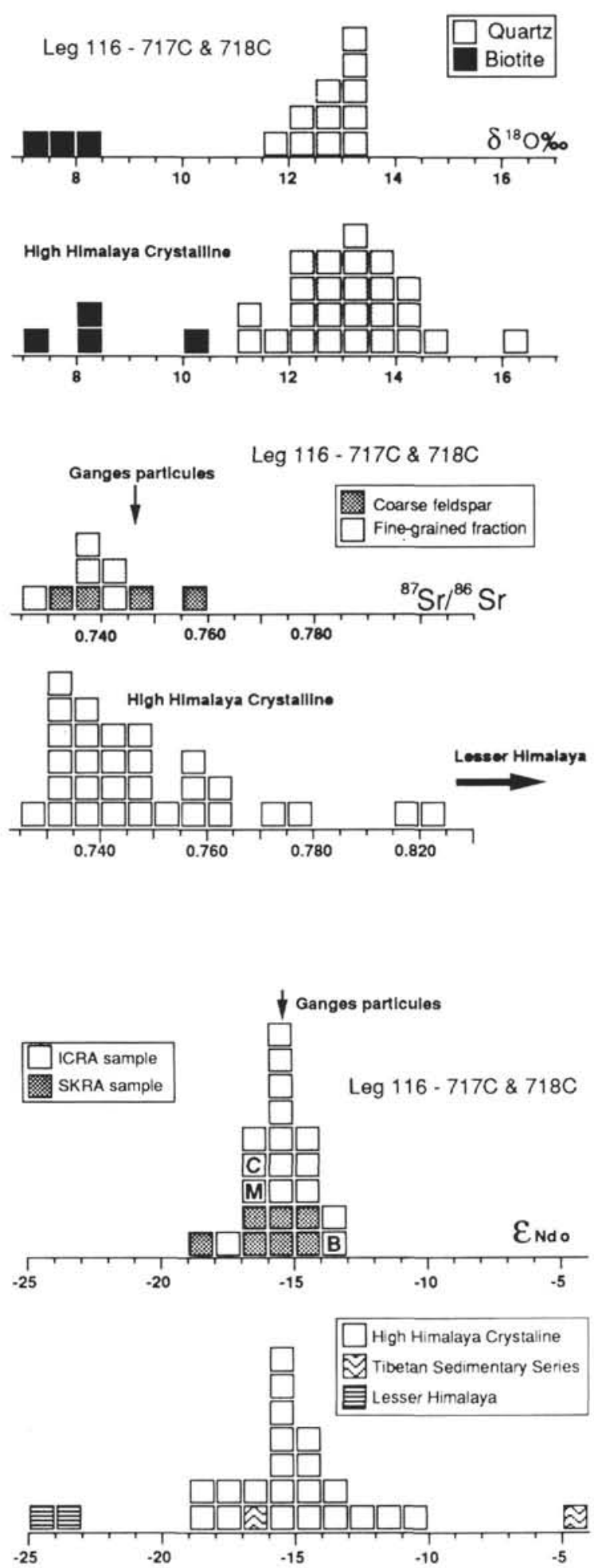

Figure 9. Histograms of O-, Sr-, and Nd-isotope data of the Leg 116 samples compared to the Himalayan formations. Mean values are similar for the $\mathrm{HHC}$ and the Leg 116 samples, but ranges are smaller for Leg 116 samples. For Nd isotope data, B, M, C represent the values of the coarse biotite + chlorite, the coarse muscovite, and the clayey fractions, respectively, of a single ICRA sample (116-717C2H-1). Data are from Table 2 and: Blattner et al. (1983), Dietrich and Gansser (1981), Deniel et al. (1986 and 1987), France-Lanord et al. (1988), France-Lanord and Le Fort, (1988), France-Lanord and Scaillet (1989), S. Goldstein (pers. comm.), Goldstein et al. (1984), Vidal et al. (1982 and 1984).

\section{Neodymium}

Ratios of ${ }^{143} \mathrm{Nd} /{ }^{144} \mathrm{Nd}$, and $\mathrm{Sm}$ and $\mathrm{Nd}$ concentrations (Table 2) were measured on the finest fraction. From recent work (McLennan et al., 1989) such material should be the most sensitive to the addition of material derived from oceanic crust. The ${ }^{143} \mathrm{Nd} /{ }^{144} \mathrm{Nd}$ ratios vary from 0.51168 to 0.51193 with most of the values close to 0.51180 . The ${ }^{147} \mathrm{Sm} / 144 \mathrm{Nd}$ values vary from 0.111 to 0.126 with a mean value of 0.119 . These ranges are in the field of most river and aeolian particles (Goldstein et al., 1984). The values of the isotopic ratios appear to be independent of the depth. $\epsilon \mathrm{Nd}_{\mathrm{o}}$ values are very similar to those of the Ganges particles (Goldstein et al., 1984) and to the High Himalaya gneisses (Deniel et al., 1987) (Fig. 9).

Within a single sample (116-717C-2H-1) the biotite-chlorite fraction $>63 \mu \mathrm{m}$ has a ${ }^{143} \mathrm{Nd} /{ }^{144} \mathrm{Nd}$ ratio significantly higher than that of both the fraction $<2 \mu \mathrm{m}$ and the muscovite $>63$ $\mu \mathrm{m}$ (Fig. 9).

To compare these results with Himalayan formations, some Nd data have also been obtained from Himalayan series rocks that were not previously investigated for their Sm-Nd characteristics. Results and calculated $\epsilon \mathrm{Nd}_{\mathrm{o}}$ values are listed in Table 2.

\section{Strontium}

${ }^{87} \mathrm{Sr} /{ }^{86} \mathrm{Sr}$ ratios of feldspars $>63 \mu \mathrm{m}$ vary between 0.733 and 0.760 independently of the depth. Clay fractions vary between 0.7099 and 0.760 , with most samples in the same range as that of the feldspars. The two samples with the lowest ratios contain calcium carbonates. A leaching experiment on Sample $116-717 \mathrm{C}-65 \mathrm{X}-3,29-30 \mathrm{~cm}$, shows that the silicate residue has $a^{87} \mathrm{Sr} /{ }^{86} \mathrm{Sr}$ ratio $=0.729$ that is only slightly lower than in other clays. The carbonate fraction has a high $\mathrm{Sr}$ content (1075 ppm) but a low ${ }^{87} \mathrm{Sr} /{ }^{86} \mathrm{Sr}$ ratio $(0.709062)$. This value is close to that of ambient seawater (De Paolo and Ingram, 1985).

The values for carbonate-free samples are higher than the range for most recent sediments derived from continental crust reported by Goldstein (1988) for which exchange with, or addition of nonradiogenic $\mathrm{Sr}(<0.710)$ is inferred. Hence the analyzed clays are dominated by crustal strontium. Interaction with seawater is not detectable.

\section{DISCUSSION}

\section{Origin of the Detrital Input}

Considering the volume and location of the Bengal Fan (Curray and Moore, 1971; Moore et al., 1974), the Himalayas must be the major detrital source. However, considering the location of the Leg 116 holes (Fig. 1), other sources are possible such as the eastern coast of India and Sri Lanka.

The clay mineralogy as well as the $\mathrm{H}-, \mathrm{O}-, \mathrm{Sr}-$, and $\mathrm{Nd}$ isotope ratios of ICRA samples (essentially illite + chlorite) and the coarse-grained mineralogy are similar to those of some Himalayan formations (Fig. 9). Ingersoll and Suczek (1979) came to the same conclusion using detailed post-counting of the coarse minerals from the Nicobar and Bengal fans (Sites 211 and 218). The coarse-grained fraction mineralogy, including amphibole, tourmaline, and garnet, is typical of both metamorphic gneisses and granites.

The clay fraction, illite and chlorite, may be derived by the degradation of muscovite and biotite of the metamorphic and igneous formations. Chlorite is also common in low-grade metamorphic rocks, and illite and chlorite are present in some sedimentary series of the Himalayas (e.g., Mukherjee, 1964). Illite and chlorite are always abundant in all stages between the Himalayas and the Leg 116 sites: in the suspended matter 
$\Delta$ Biotite+chlorite $(>63 \mu \mathrm{m}) \Delta$ Muscovite $(>63 \mu \mathrm{m}) \quad$ a ICRA $(<2 \mu \mathrm{m})$ व SKRA $(<2 \mu \mathrm{m})$

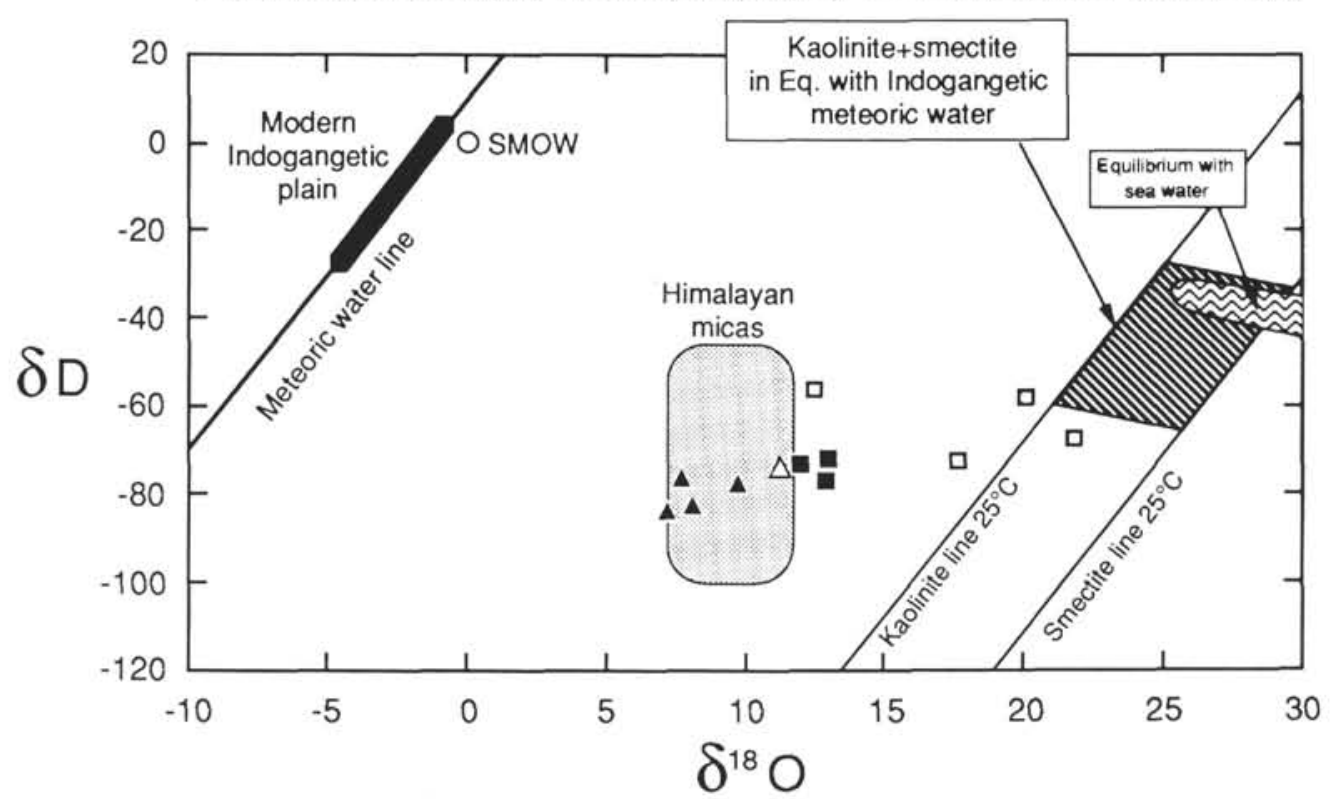

Figure $10 . \delta \mathrm{D}$ vs. $\delta^{18} \mathrm{O}$ plot of the Leg 116 micas and clays $(\% c)$ compared with the field of the micas of the Himalaya (France-Lanord, 1987) and the field for kaolinite and smectite in equilibrium with modern meteoric water of the Indo-Gangetic plain. Lines of Kaolinite and smectite in equilibrium with meteoric water are drawn according to the fractionation factors of Lawrence and Taylor (1972), Yeh and Savin (1976) and Yeh (1980). Meteoric waters from the Indo-Gangetic Plain correspond to mean annual values given by International Atomic Energy Agency (1979) in New Delhi $\left(\delta^{18} \mathrm{O} \approx-5 \%\right)$ and Shillong $\left(\delta^{18} \mathrm{O} \approx 0 \%\right)$ (Fig. 1).

of the Ganges and Brahmaputra rivers (Konta, 1985; Naidu et al., 1985), in the soils of the Indo-Gangetic Plain (Sidhu and Gilkes, 1977), and in the surficial sediments of proximal and medial parts of the Bay of Bengal (Bouquillon, 1987) (Fig. 11). Similar assemblages are also characteristic of the Indus deepsea fan (Bouquillon et al., in press).

The origin of smectite and kaolinite is more difficult to establish. Neither are abundant in Himalayan formations. Hence they may have an origin other than direct Himalayan input. $\delta \mathrm{D}$ and $\delta^{18} \mathrm{O}$ values of SKRA samples show that they are certainly detrital and that they contain a substantial proportion of soil clays. Moreover, similar smectites from proximal and medial parts of the Ganges Fan have Aluminum and iron content ( $20 \%$ and $12 \%$ respectively, BouquilIon, 1987; Bouquillon et al., in press) typical of soil (Paquet, 1970). Two major sources can therefore be considered: (1) the soils of the Indo-Gangetic Plain where Himalayan material has accumulated and been altered, and (2) the eastern coast of India and Sri Lanka. Of the seven SKRA samples analyzed for $\epsilon_{\mathrm{N}} \mathrm{d}_{\mathrm{o}}$, six have values similar to those of ICRA levels. SKRA minerals could therefore be produced by alteration of Himalayan minerals, which would support a source from the Indo-Gangetic Plain. However, the abundance of kaolinite is not entirely compatible with a unique Gangetic origin. Based on the observation of Gibbs (1975), differential settling of kaolinite and smectite should induce a decrease of the kaolinite/smectite ratio with distance from the source. Across the Bengal Fan, no such gradient in this ratio is observed either from west to east or north to south. This suggests that a part of the clay assemblages must have originated from along the whole length of the western Bay of Bengal coast. Southern India and Sri Lanka could act as a source for the smectites and kaolinites because (1) they are relatively close to the Leg 116 Sites, (2) clay assemblages of the Holocene sediments in the Ceylon Basin are very similar to those of SKRA horizons at Sites 717 and 718
(Fig. 12), (3) Tertiary lateritic formations from south India are rich in kaolinites and gibbsite (Kumar, 1986). Only one Sample $(116-717 \mathrm{C}-65 \mathrm{X}-3,29-30 \mathrm{~cm})$ has $\epsilon \mathrm{Nd}_{\mathrm{o}}$ and ${ }^{87} \mathrm{Sr} /{ }^{86} \mathrm{Sr}$ ratios lower than the bulk range of Leg 116 samples. These isotopic values are extreme for Himalayan formations and are more similar to values of the southern India Archean formations (Peucat et al., 1989). However, in most samples such a contribution may be diluted by Himalayan material sensu lato and is therefore not detectable by bulk isotopic analysis.

TURBIDITES

Clay assemblages $(\%)$
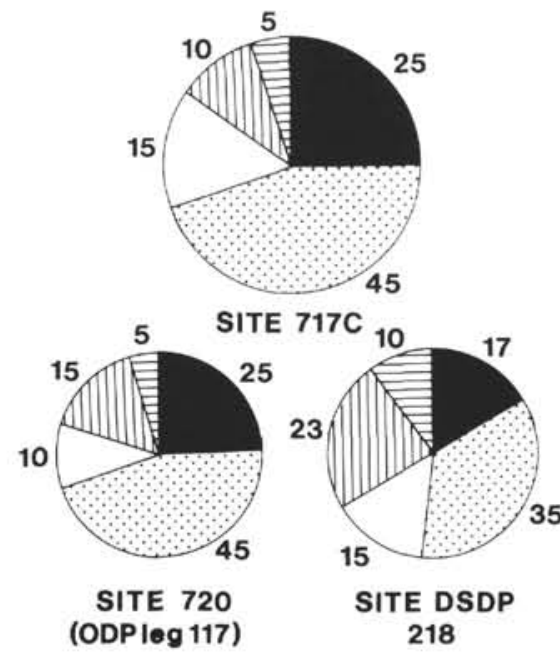

Figure 11. Comparison of clay assemblages in turbidites of Sites 116-717C, 117-720 and 22-218. See Figure 1 for location of Site 22-218, and Figure 7 for legend. 
BIOCLASTIC TURBIDITES

Clay assemblages $(\%)$

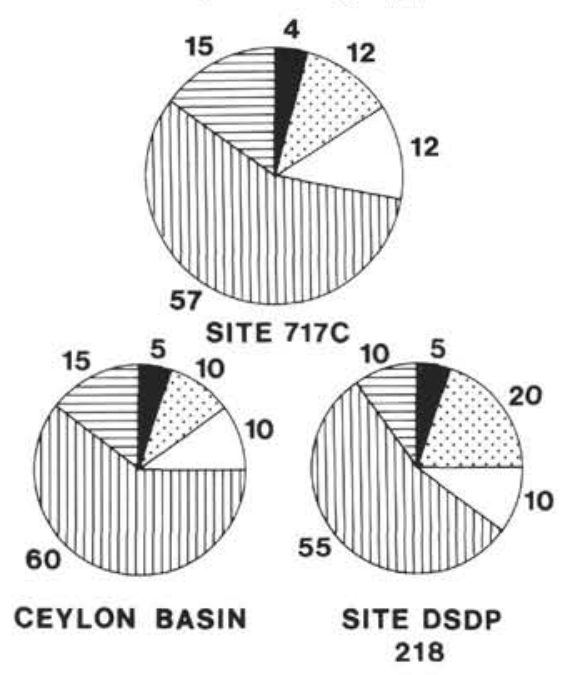

Figure 12. Comparison of clay assemblages in calcareous muddy oozes of Site 116-717C, 22-218, and the Ceylon Basin. See Figure 7 for legend.

At present it is impossible to ascertain the mineralogical composition and the relative contribution of these two sources. It appears that the Indo-Gangetic Plain is a potential source of smectite and that a meridional source richer in kaolinite could better explain the occurrence of this mineral. One answer could be the chemistry of smectite, because south India and Sri Lanka soils contain a special type of ferrous smectite $\left(21 \% \mathrm{Fe}_{2} \mathrm{O}_{3}\right)$. Additional isotopic analyses of SKRA levels and chemical analyses are necessary to refine the model.

Palygorskite, observed in biogenic-rich sediments of Zone 2 (Pleistocene), has already been found in the Pleistocene sediments of the Sri Lanka Basin (Bouquillon et al., in press). Their fibers, short and often broken, are typical of aeolian inputs (Chamley et al., 1989). Palygorskite is typical of saline deserts, and Somalia and Arabia are the major sources recognized for the northern Indian Ocean (Kolla et al., 1976; Bouquillon and Debrabant, 1987; Chamley et al., 1989; Debrabant et al., unpubl. data).

\section{Temporal Evolution of the Detrital Input}

The changes in mineralogy of the Leg 116 turbidites can be summarized in three periods corresponding to the three zones. Zones 3 ( 17 to $\approx 6$ m.y.) and 1 ( $\approx 0.8 \mathrm{~m} . \mathrm{y} . ?$ to present) record periods of high detrital input and are rich in minerals directly derived from the Himalayas. By contrast, Zone 2 corresponds to a period when detrital input was dominated by alteration minerals associated with bioclastic constituents, with only few brief silt turbidite episodes. In Hole $717 \mathrm{C}$ the period of Zone 2 is characterized by low sedimentation rates $(\approx 48 \mathrm{~m} / \mathrm{m} . \mathrm{y}$.) compared to Zones $3(\approx 101 \mathrm{~m} / \mathrm{m} . \mathrm{y}$.) and $1(\approx 260 \mathrm{~m} / \mathrm{m} . \mathrm{y}$.) (Shipboard Scientific Party, 1989). This contrast is much more marked in Hole $718 \mathrm{C}$, where the sedimentation rate was around $10 \mathrm{~m} / \mathrm{m}$.y. during the period of Zone 2 and $70 \mathrm{~m} / \mathrm{m}$.y. during the period of Zone 3 .

The variation of the direct Himalayan input can be interpreted either in terms of climatic change and sea-level variation or in terms of an erosion pulse. The very high sedimentation rate recorded during the last million $\mathrm{yr}$ in Hole $717 \mathrm{C}$ can be correlated to the deposition of very thick $(\approx 3000 \mathrm{~m})$ molasse in the central Himalayas during the Pleistocene (e.g.,
Le Fort, 1989). In the Himalayas the uplift rate is probably controlled by continental thrusting. The time interval between the two major thrusts, the main central thrust (MCT) and the main boundary thrust (MBT), could correspond to a period of lower erosion rates.

While the nature of the detrital input can be summarized by three major periods, the isotopic compositions of $\delta^{18} \mathrm{O}$ of quartz, ${ }^{87} \mathrm{Sr} /{ }^{86} \mathrm{Sr}$ of feldspar, and ${ }^{143} \mathrm{Nd} /{ }^{144} \mathrm{Nd}$ of fine particles are nearly constant throughout the two profiles. Therefore, from the isotopic point of view, the source(s) of minerals during these different periods did not change.

\section{Comparison with the Himalayas}

As shown by the mineralogical and isotopic (Fig. 9) data, all ICRA levels and some SKRA samples have characteristics similar to those of certain Himalayan formations. A more detailed comparison requires a clear definition of the different Himalayan candidates. Schematically, the Himalayas can be subdivided into three major units from south to north (e.g., Gansser, 1964; Le Fort, 1989):

1. The lesser Himalaya ( $\mathrm{LH})$, dominated by metasediments that are the oldest known formations $(>1.8 \mathrm{Ga}$; Deniel, 1985). They are located between the MBT and the MCT (Fig. 1). $\mathrm{Sr}$ isotope ratios are very high, reflecting their long crustal evolution (France-Lanord and Le Fort, 1988). Two $\epsilon \mathrm{Nd}_{0}$ values (Table 2) corroborate this evolution.

2. The High Himalaya Crystallines (HHC), located over the MCT (Fig. 1), are mostly paragneisses. They are often associated with thick leucogranitic plutons. They are the most thoroughly investigated of the various Himalayan formations. $\mathrm{O}, \mathrm{Sr}$, and $\mathrm{Nd}$ isotope ranges of the paragneisses are presented in Figure 9. Leucogranites, which are derived from the $\mathrm{HHC}$, have exactly similar ranges but they do not represent an important source of sediments compared to the whole HHC.

3. The High Himalaya sedimentary series (HHSS) are Cambrian to Eocene composite formations including limestones, sandstone, shales, and volcanic material. Only two $\mathrm{Nd}$ isotope values (this study, Table 2) are available. One from a Jurassic schist (NA 178) is in the range of HHC and the other from a Cretaceous volcano-detritic sandstone (NA 181) has a much higher $\epsilon \mathrm{Nd}_{\mathrm{o}}$ value.

In terms of radiogenic isotopes, $\mathrm{LH}$ and $\mathrm{HHC}$ are clearly distinguishable, whereas HHSS need more investigation. However, their nature dictates certain constraints: (1) HHSS are rich in carbonate rocks (up to $50 \%$ in central Nepal) that should have ${ }^{87} \mathrm{Sr} /{ }^{86} \mathrm{Sr}<0.710$ and be $\mathrm{Nd}$ poor, (2) the shales can be either similar to the HHC or very different if volcanic material is present. Therefore the detrital input of the HHSS should have a highly variable signature.

For the $\delta \mathrm{D}$ values, the different Himalayan formations display some ranges of values that allow discrimination. In central Nepal, LH is dominated by low $\delta \mathrm{D}$ content $(-100 \%$ to $-70 \%$ ) rocks, $\mathrm{HHC}$ have higher $\delta \mathrm{D}$ values around $-60 \%$ to $-50 \%$ for muscovite and $-93 \%$ o to $-68 \%$ o for biotite and HHSS is often very $\delta \mathrm{D}$ depleted $(-140 \%$ to $-80 \%$ for biotite) (France-Lanord, 1987; France-Lanord et al., 1988).

The $\delta \mathrm{D}$ values of ICRA samples, $-73 \%$ to $-83 \%$, correspond to both HHC and LH. Figure 9 clearly shows that the $\mathrm{O}, \mathrm{Sr}$, and $\mathrm{Nd}$ isotope data of Leg 116 samples are indistinguishable from those for the HHC formations. For all three isotopic systems the maxima of the histograms are concordant, and the ranges of values are slightly smaller for Leg 116 samples. The $\mathrm{Sr}$ and $\mathrm{Nd}$ isotope maxima correspond also to the ${ }^{87} \mathrm{Sr} /{ }^{86} \mathrm{Sr}(\approx 0.747)$ and the $\epsilon \mathrm{Nd}_{\mathrm{o}}(-15.3)$ for the particles presently being carried by the Ganges (Fig. 9) (S. Goldstein, 
pers. comm., 1988; Goldstein et al., 1984). The isotopic similarity between Ganges particles and $\mathrm{HHC}$ is not surprising, as now, among the Himalayan formations, $\mathrm{HHC}$ is by far the most exposed to physical erosion. Therefore, a simple model would be to propose that since $17 \mathrm{Ma}$ the material eroded from the Himalaya is provided by the HHC. Obviously other Himalayan formations have been and are being eroded and the model of a single source for the detrital sediments is an over-simplification. The isotopic heterogeneities of the HHC are typically on a metric to decametric scale (Deniel et al., 1987; France-Lanord et al., 1988), and the mechanism of erosion/transport should reduce the heterogeneities by mixing. Because the $\mathrm{O}, \mathrm{Sr}$, and $\mathrm{Nd}$ isotope ranges are nearly the same as in the HHC, a small contribution of other formations is probable. For example, roughly $20 \%$ of LH is necessary to explain the lower $\epsilon \mathrm{Nd}_{\mathrm{o}}$ values. Such contributions are confirmed by the single-grain ${ }^{40} \mathrm{Ar} /$ ${ }^{39} \mathrm{Ar}$ dating (Copeland et al., this volume): while feldspars from the $\mathrm{HHC}$ are younger than $40 \mathrm{~m} . \mathrm{y}$., most levels from Holes $717 \mathrm{C}$ and $718 \mathrm{C}$ contain some old feldspars (100 m.y. to 2 G.y.) that have not undergone the same degree of metamorphism as the HHC. The high abundance of chlorite, even in the coarse fraction, compared with that of the present $\mathrm{HHC}$ formations, also supports mixing of additional sources with the HHC.

\section{CONCLUSION}

During the 17-m.y. record of the Leg 116 Holes, the Bengal Fan sedimentation has been dominated by detrital and turbiditic inputs. Both the mineralogy and the combined isotopic compositions are compatible with a Himalayan origin for the major part of the input. This conclusion is particularly well supported because the three isotopic systems are independent of one another. Except during the 6- to 1-m.y. period, the mineralogical assemblages are poor in alteration minerals. The very high sedimentation rates, the low $\delta^{18} \mathrm{O}$ and high ${ }^{87} \mathrm{Sr} /{ }^{86} \mathrm{Sr}$ values (unusual for detrital material) all suggest that the processes of erosion, transport, and deposition were very intense and rapid. These characteristics are of course related to the dramatic development of the Himalaya, where uplift rates reached $1000 \mathrm{~m} / \mathrm{m}$.y. The long history of sedimentation also implies that the Himalayan relief has existed at least since the middle Miocene. Whereas the mineralogical assemblages and the rate of sedimentation are variable, especially during the 6- to 1-m.y. period, the Nd-isotope signature, which is the most reliable witness of the origin, is remarkably similar throughout the studied $17 \mathrm{~m} . \mathrm{y}$. This stability implies that the major source of eroded material remained the same during the 17 m.y. and therefore that the High Himalaya Crystalline or similar formations have always been the most exposed to erosion.

\section{ACKNOWLEDGMENTS}

Jean Jacques Tiercelin thanks ODP for inviting him to participate on Leg 116. The link between sedimentologists and geochemists for this study was initiated by Francis Albarède. This research was supported by a grant from CNRS ASP "Soutien ODP-France." We thank warmly Simon M. F. Sheppard, who sacrificed his spare time to improve the English of this manuscript, and Patrick Le Fort who provided some Himalayan samples and constructive discussion. We greatly appreciated helpful comments by three anonymous reviewers. The assistance of Danielle Dautel and Pierre Coget in isotopic analyses is gratefully acknowledged.

\section{REFERENCES}

Alibert, C., Michard, A., and Albarède, F., 1983. The transition from alkali basalts to kimberlites: isotope and trace element evidence from melilites. Contrib. Mineral. Petrol., 82:176-186.
Beutelspacher, H., and Van der Marel, X., 1968. Atlas of Electron Microscopy of Clays Minerals and their Admixtures: New York (Elsevier).

Blattner, P., Dietrich, V., and Gansser, A., 1983. Contrasting ${ }^{18} \mathrm{O}$ enrichment and origins of High Himalayan and Transhimalayan intrusives. Earth. Planet. Sci. Lett., 65:276-286.

Bouquillon, A., 1987. Influence continentales et marines dans les sédiments Cénozoiques de l'ocean Indien Nord Oriental [Unpublished Thèse doct.]. Univ. Lille Flandres-Artois, France.

Bouquillon, A., Chamley, H., and Froehlich, F., 1989. Sédimentation argileuse au Cénozoïque supérieur dans l'océan Indien nordoriental. Oceanol. Acta, 12:133-147.

Bouquillon, A., and Debrabant, P., 1987. Distribution des minéraux argileux dans l'Océan Indien Nord Oriental. J. Rech. Oceanogr., 12:8-11.

Bouquillon, A., Debrabant, P., Nitsuma, N., Prell, W., and Shipboard Scientific Party, Leg 117, 1988. Clay mineralogy in Neogene to quaternary sediments of the NW Indian Ocean. 69th IAS Regional Meeting Sedimentol., Leuven. (Abstract)

Capet, X., Chamley, H., Beck, C., and Holtzapffel, T., 1990. Clay mineralogy of ODP Sites 671 and 672, Barbados Ridge Accretionnary complex and Atlantic Abyssal Plain: palaeoenvironmental and diagenetic implications. In Mascle, A., Moore, J. C., et al., Proc. ODP, Sci. Results, 110: College Station, TX (Ocean Drilling Program), 85-96.

Chamley, H., Debrabant, P., and Bouquillon, A., 1989. Environmental signifiance of detrital palygorskite in late Cenozoic sediments of the Northwestern Indian ocean. AIPEA, 9: Strasbourg, Austria (abstract).

Clayton, R. N., Jackson, M. L., and Sridar, K., 1978. Resistance of quartz silt to isotopic exchange under burial and intence weathering conditions. Geochim. Cosmochim. Acta, 42:1517-1522.

Clayton, R. N., and Mayeda, T. D., 1963. The use of bromine pentafluoride in the extraction of oxygen from oxides and silicates for isotopic analysis. Geochim. Cosmochim. Acta, 27:43-52.

Curray, J. R., and Moore, D. G., 1971. Growth of the Bengal deepsea fan and denudation of the Himalayas. Geol. Soc. Am. Bull., 82:563-572.

Deniel, C., 1985. Apport des isotopes du $\mathrm{Sr}$, du $\mathrm{Nd}$ et du $\mathrm{Pb}$ à la connaissance de l'âge et de l'origine des leucogranites himalayens. Exemple du Manaslu (Himalaya, Népal) [Unpublished Thèse doct.]. Univ. Clermont-Ferrand, France.

Deniel, C., Vidal, P., Fernandez, A., and Le Fort, P., 1987. Isotopic study of the Manaslu granite (Himalaya, Nepal): inferences on the age and source of Himalayan leucogranites. Contrib. Mineral. Petrol., 96:78-92.

Deniel, C., Vidal, P., and Le Fort, P., 1986. Les leucogranites himalayens et leur région source probable: les gneiss de la "Dalle du Tibet." C. R. Acad. Sci. Ser. 2, 303:57-60.

DePaolo, D. J., and Ingram, B. L., 1985. High-resolution stratigraphy with strontium isotopes. Science, 227:938-941.

Dietrich, V., and Gansser, A., 1981. The leucogranites of the Bhutan Himalaya (crustal anatexis versus mantle melting). Schweiz. Minéral. Pétrogr. Mitt., 61:177-202.

Dunoyer de Segonzac, G., 1969. Les minéraux argileux dans la diagenése passage au métamorphisme. Mèm. Serv. Carte Geol. Alsace Lorraine, Thèse doctorat, Faculté des Sciences de l'Université de Strasbourg, 29:320.

France-Lanord, C., 1987. Chevauchement, métamorphisme et magmatisme en Himalaya du Népal Central. Etude isotopique $\mathrm{H}, \mathrm{C}, \mathrm{O}$ [Unpublished Thèse Doct.]. Inst. Natl. Polytech. de Lorraine, France.

France-Lanord C., and Le Fort, P., 1988. Crustal melting and granite genesis during the Himalayan collision orogenesis. Trans. R. Soc. Edinburgh: Earth Sci., 79:183-195.

France-Lanord C., and Scaillet B., 1989. Emplacement of the Gangotri leucogranite: stable isotope constraint. Terra Cognita, 1:174 (abstract).

France-Lanord, C., Sheppard, S.M.F., and Le Fort, P., 1988. Hydrogen and oxygen isotope variations in the High Himalaya peraluminous Manaslu leucogranite: evidence for heterogeneous sedimentary sources. Geochim. Cosmochim. Acta, 52:513-526.

Friedman, 1., 1953. Deuterium content of natural water and other substances. Geochim. Cosmochim. Acta, 4:89-103. 
Gansser, A., 1964. Geology of the Himalayas: New York (Wiley).

Gansser, A., 1966. The Indian Ocean and the Himalayas, a geological interpretation. Eclogae Geol. Helv., 59:831-848.

Garlick, G. D., and Epstein, S., 1967. Oxygen isotope ratios in coexisting minerals of regionally metamorphosed rocks. Geochim. Cosmochim. Acta, 31:181-214.

Gibbs, R. J., 1975. Settling velocity, diameter and density for flocs of illite, kaolinite and montmorillonite. J. Sediment. Petrol., 55:6568.

Goldstein, S. L., 1988. Decoupled evolution of $\mathrm{Nd}$ and $\mathrm{Sr}$ isotopes in the continental crust and the mantle. Nature, 336:733-738.

Goldstein, S. L., O'Nions, R. K., and Hamilton, P. J., 1984. A Sm-Nd isotopic study of atmospheric dusts and particulates from major river systems. Earth. Planet. Sci. Lett., 70:221-236.

Graham C. M., Viglino J. A., and Harmon R. S., 1987. An experimental study of hydrogen isotope exchange between aluminous chlorite and water. Am. Mineral., 72:566-579.

Holtzapffel, T., 1985. Les minéraux argileux. Préparation-Analyse diffractométrique et détermination. Soc. Gèol. Nord, 12:136.

Ingersoll, R. V., and Suczek, C. A., 1979. Petrology and provenance of Neogene sand from Nicobar and Bengal fans, DSDP Sites 211 and 218. J. Sediment. Petrol., 49:1217-1228.

International Atomic Energy Agency, 1979. Environmental isotope data No. 6: world survey of isotope concentration in precipitation (1972-1975). Tech. Rep. Ser., I.A.E.A., 192.

Kolla, V., Henderson, L., Biscaye, P. E., 1976. Clay mineralogy and sedimentation in the western Indian ocean. Deep-Sea Res., 23:941-949.

Konta, J., 1985. Crystalline minerals and chemical maturity of suspended solids of some major world rivers. Mineral. Petrogr. Acta, 29A:121-123.

Kumar, A., 1986. Paleolatitudes and the age of indian laterites. Palaeogeogr., Palaeoclimatol., Palaeoecol., 53:231-239.

Lawrence, J. R., and Taylor, H. P., 1972. Hydrogen and Oxygen isotope systematics in weathering profiles. Geochim. Cosmochim. Acta, 36:1377-1393

Le Fort, P., 1989. The Himalayan orogenic segment. In Sengör, A.M.C (Ed.), Tectonic evolution of the Tethyan regions. Proc. NATO ASI meeting, Istanbul, October 1985. Amsterdam (D. Reidel).

Leg 116 Shipboard Scientific Party, 1987. Collision in the Indian Ocean. Nature, 330:519-521.

McLennan, S. M., McCulloch, M. T., Taylor, S. R., and Maynard, J. B., 1989. Effect of sedimentary sorting on neodymium isotopes in deep-sea turbidites. Nature, 337:547-549.

Michard, A., Gurriet, P., Soudant, M., and Albarède, F., 1985. Nd isotopes in French Phanerozoic shales: external vs. internal aspects of crustal evolution. Geochim. Cosmochim. Acta, 49:601610.

Milliman, J. D., and Meade, R. H., 1983. World delivery of river sediment to the oceans. J. Geol., 1:1-21.

Moore, D. G., Curray, J. R., Raitt, R. W., and Emmel, F. J., 1974. Stratigraphic-seismic section correlation and implications to Bengal Fan history. In von der Borch, C. C., Sclater, J. G., et al., Init. Repts. DSDP, 22: Washington (U.S. Govt. Printing Office), 403412 .
Mukherjee, B., 1964. Clay minerals in argillaceous sediments of the Himalayan zone. Clay Miner., 5:363-372.

Naidu, A. S., Mowatt, J. C., Somayajulu, B.L.K., and Sreeramachandra Rao, K., 1985. Characteristics of clay minerals in the bed loads of major rivers of India. In Degens, E. T., Kempe, S., and Herrera, R. (Eds.), Transport of Carbon and Minerals in Major World Rivers, Part 3. Min. Geol. Palaeont. Inst. Univ. Hamburg, SCOPE/UNEP Sonderbard, 58:559-568.

Paquet, M., 1970. Evolution géochimique des minéraux argileux dans les altérations et les sols des climats méditerrannéens et tropicaux à saisons contrastées. Mèm. Serv. Carte Gèol. Alsace Lorraine, 30.

Peucat, J. J., Vidal, P., Bernard-Griffiths, J., and Condie, K. C., 1989. $\mathrm{Sr}, \mathrm{Nd}$ and $\mathrm{Pb}$ isotopic systematics in the Archean lowto-high-grade transition zone of southern India: syn-accretion granulites. J. Geol., 97:537-549.

Savin, S. M., and Epstein, S., 1970a. The oxygen and hydrogen isotope geochemistry of ocean sediments and shales. Geochim. Cosmochim. Acta, 34:43-63.

Savin, S. M., and Epstein, S., 1970b. The oxygen isotopic compositions of coarse grained rocks and minerals. Geochim. Cosmochim. Acta, 34:323-329.

Savin, S. M., and Epstein, S., 1970c. The oxygen and hydrogen isotope geochemistry of clay minerals. Geochim. Cosmochim. Acta, 34:25-42.

Shipboard Scientific Party, 1989. Sites 717-719, Bengal Fan. In Cochran, J. R., Stow, D.A.V., et al., Proc. ODP, Init. Repts., 116: College Station, TX (Ocean Drilling Program), 45-198.

Sidhu, P. S., and Gilkes, R. J., 1977. Mineralogy of soils developed on alluvium in the Indo-gangetic plain (India). Soil Sci. Soc. Am. J., 41:1194-1201.

Suzuoki T., and Epstein, S., 1976. Hydrogen isotope fractionation between $\mathrm{OH}$-bearing minerals and water. Geochim. Cosmochim. Acta, 40:1229-1240.

Taylor, H. P., Jr., and Sheppard, S.M.F., 1986. Igneous rocks: I. Processes of isotopic fractionation and isotope systematics. In Valley, J. W., Taylor, H. P., Jr., and O'Neil, J. R. (Eds.), Stable Isotopes in High Temperature Geological Processes. Mineral. Soc. Am., 16:227-272.

Vidal, Ph., Bernard-Griffiths, J., Cocherie, A., Le Fort, P., Peucat, J. J., and Sheppard, S.M.F., 1984. Geochemical comparison between Himalayan and Hercynian leucogranites. Phys. Earth. Planet. Inter., 35:179-90.

Vidal, Ph., Cocherie, A., and Le Fort, P., 1982. Geochemical investigations of the origin of the Manaslu leucogranite (Himalaya, Nepal). Geochim. Cosmochim. Acta, 46:2279-2292.

Yeh, H., 1980. D/H ratios and late-stage dehydration of shales during burial. Geochim. Cosmochim. Acta, 44:341-352.

Yeh, H., and Savin, S. M., 1976. The extent of oxygen isotope exchange between clay minerals and sea water. Geochim. Cosmochim. Acta, 40:743-748.

Date of initial receipt: 27 June 1989

Date of acceptance: 16 February 1990

Ms 116B-117 